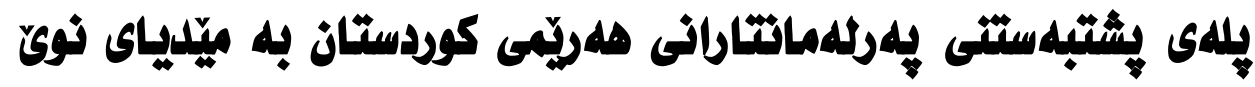

بلهرهلم خاللد احمد

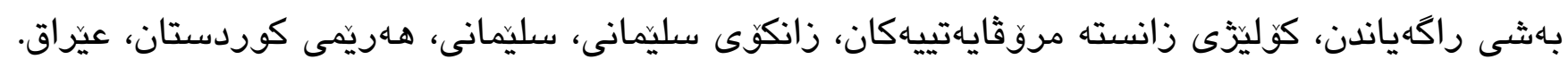

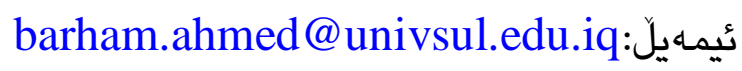

\section{فواد على أله حملد}

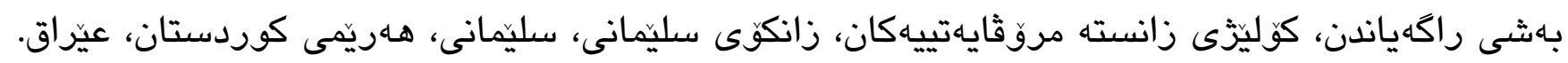

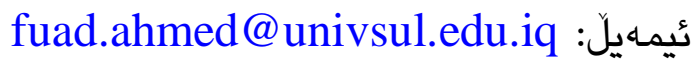

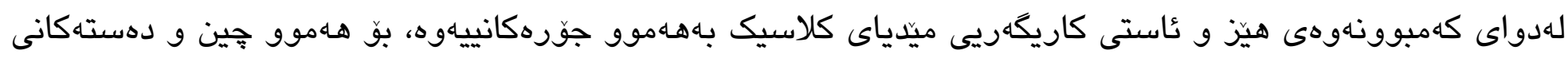

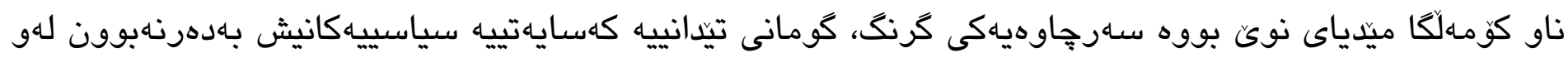

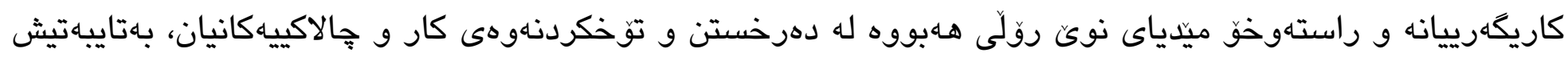

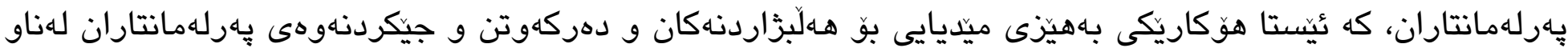
كومهلكادا بريتييه له مينّياى نوىّ.

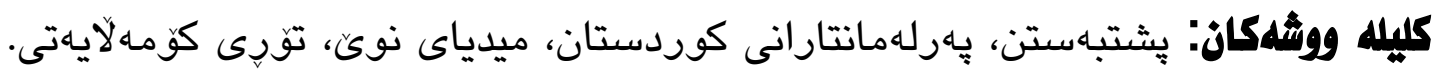




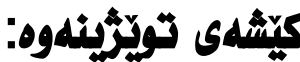

تويزّينهوهكان لهسهر بنهمايى كيشهكان بونياد دهنرين، ئهم تويَّينهوهيه باس له كيشاهيهك دهكات، كه زوربهى

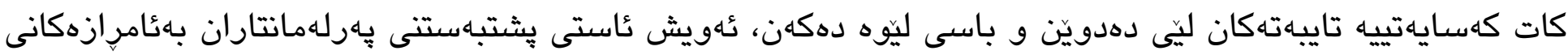
ميّديا، بهتاييهتيش ميّدياى نوىن بو كَهيشتن بهدهنكدران و كوكردنهوهى نارِزايى و هاوكارى هـهاهـانكى له نيّوان

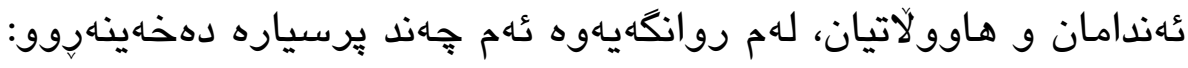

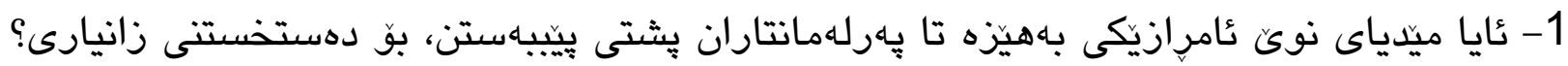

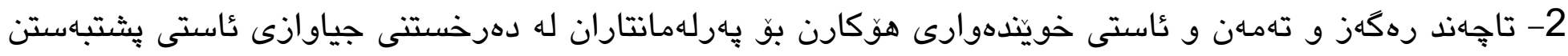

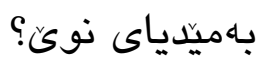

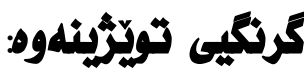

هـموو تويّزينهوهيهكى زانستى له جهاندين بواردا كَرنكى خوّى ههيه، وهك:

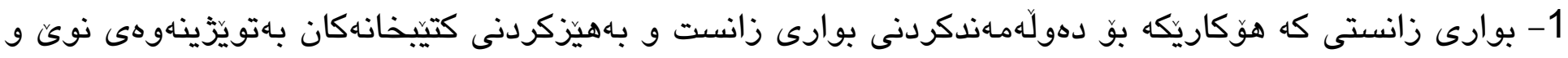
بهردييشبردنى ئاستى زانستى.

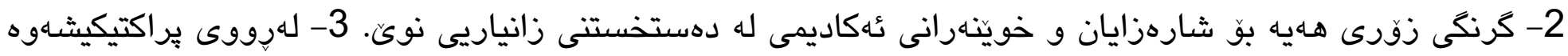

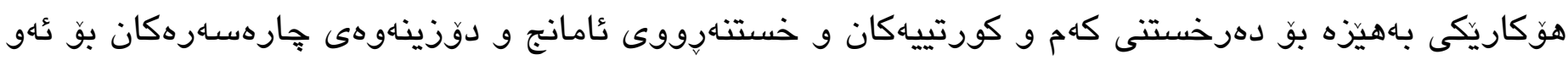
كيثنانهى روودهدهن.

\section{تُامانجى تُوِّرِينهوه:}

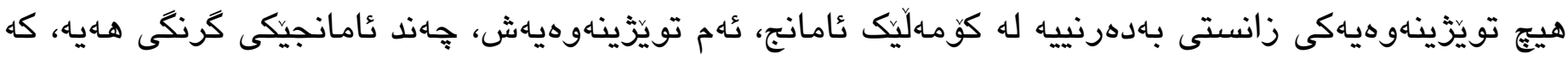

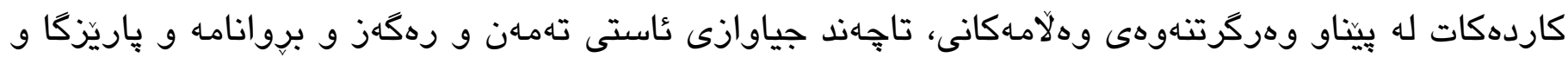

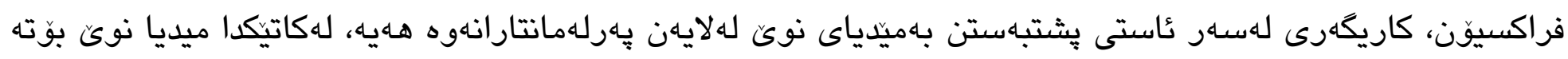

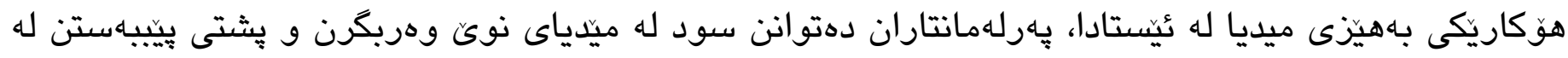

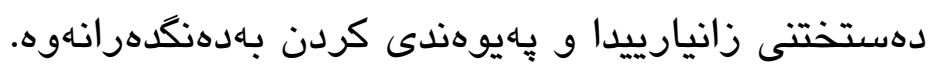

سنوروكاثى تُوِّرِينهوه:

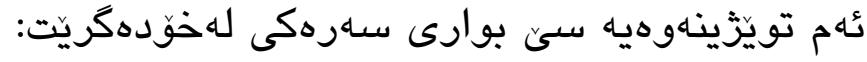

$$
\begin{aligned}
& \text { 1- بوارى مروّيى: سارجهم بֶهرلهمانتارانى كوردستان. }
\end{aligned}
$$

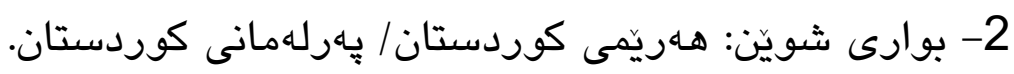

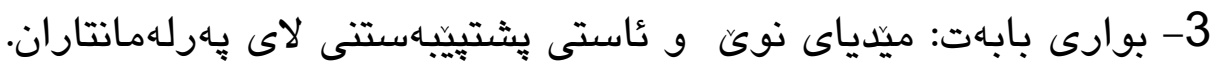

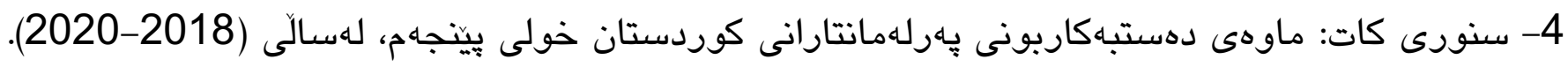




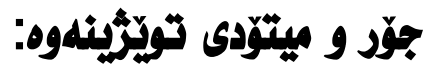

تويَّينهوهيهكى وهصفييه وميتودى رووييّو بهكارهاتووه، يشتى بهداتاكانى فوّرمى دابهشكراو باسهار

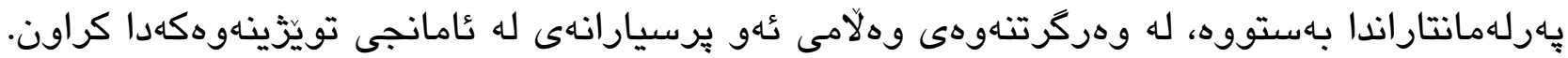

\section{ساميلى تويَّئنهوه:}

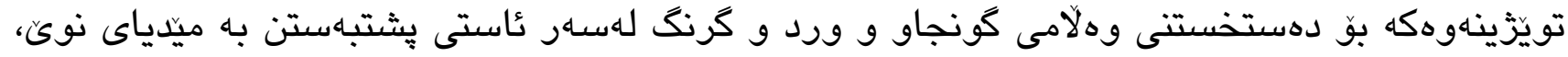

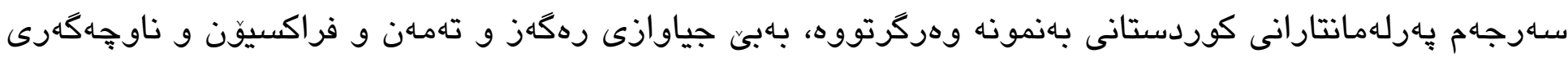

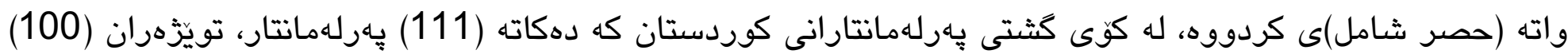

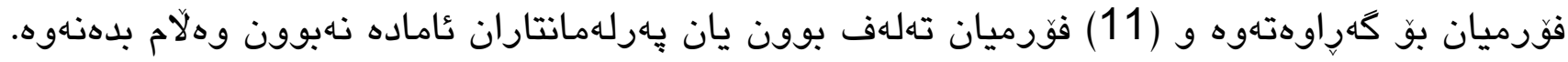

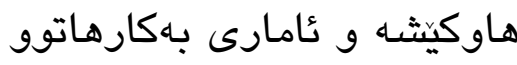

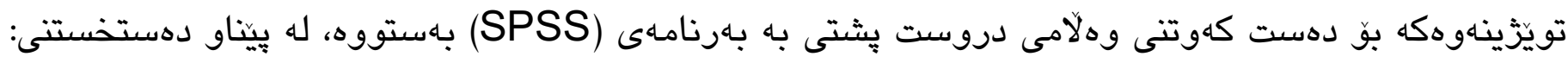
1- ناوهنده زميّره، 2- لادانى يِيّوهرى، 3- تى تيّست،

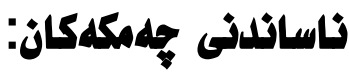

1- يشتبهستن: بهاماناى كرنكيدان بهأمرازهكانى ميديا و بهتاينهتيش عامرازى ميدياى نوكن، لهييناو كهيشتن بهو

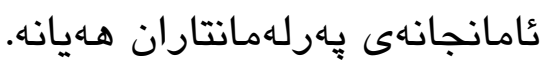

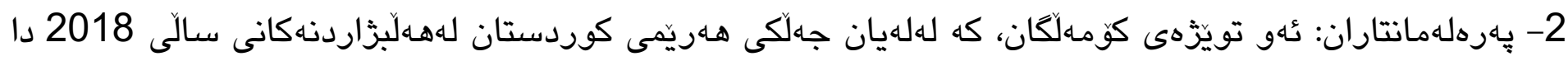

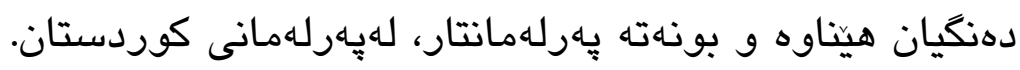

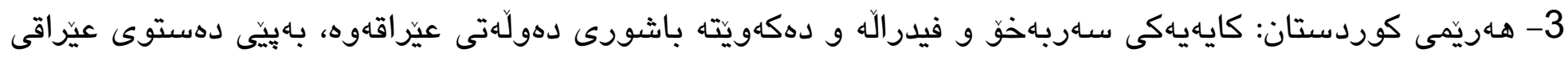

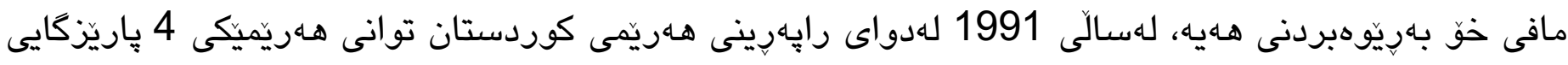

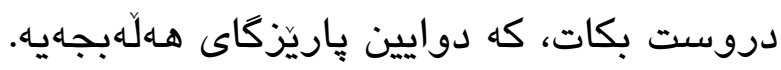

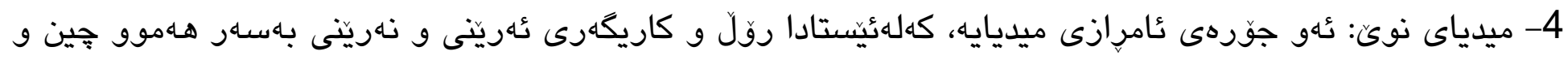
تويَّز و كايهكانى ذيانى مروّثهكانهوه هـايه.

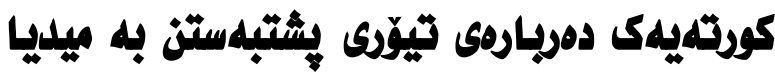

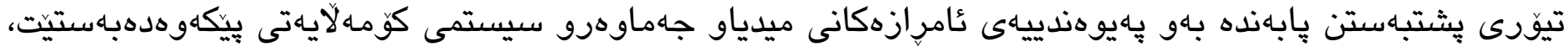

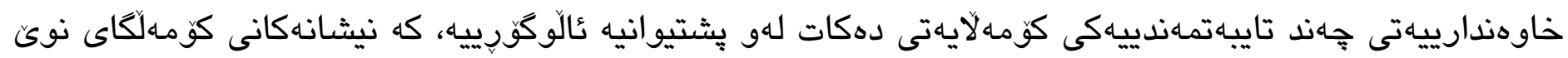

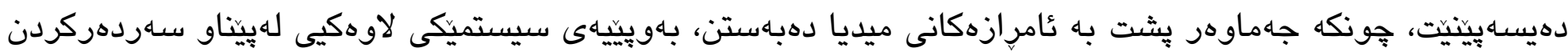


و تيكّهيشتن له سيستميكى لاوهكيى تر، كه ثٔويش دهوروبهرى كوماهلايهتييه كه تاكهكانى كَهل تيايدا دهزين؛ واته

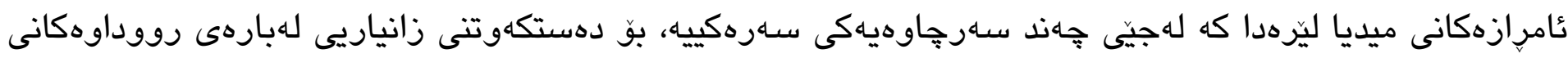

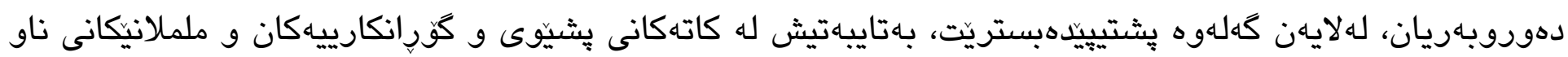

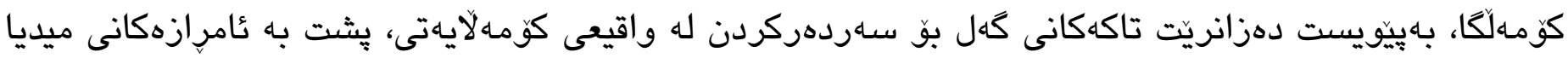

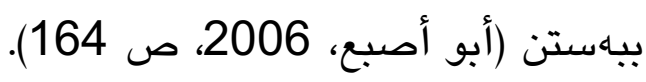

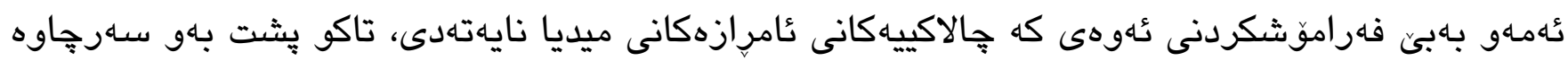

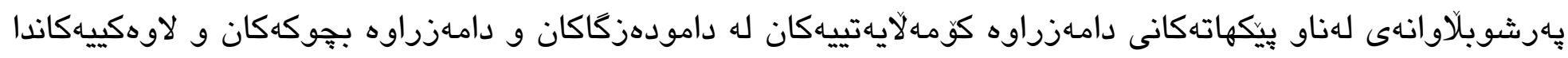

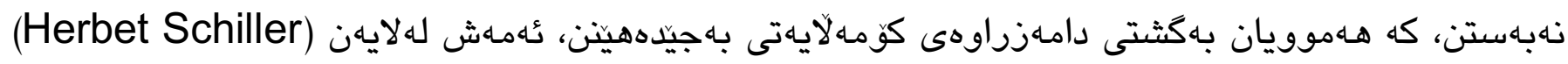

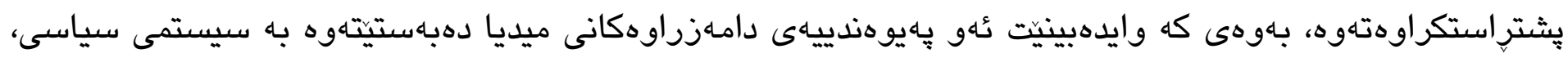

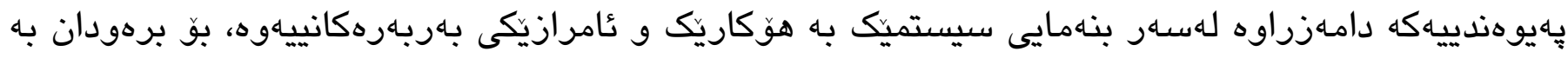

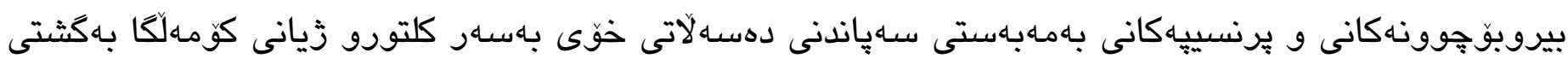

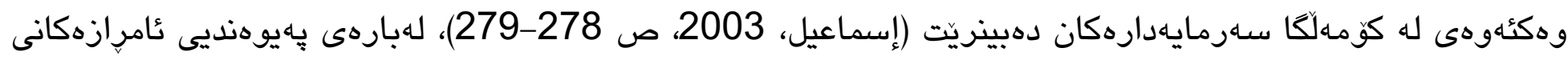

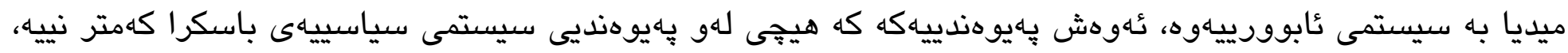

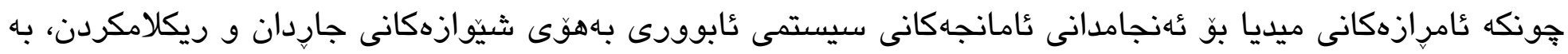

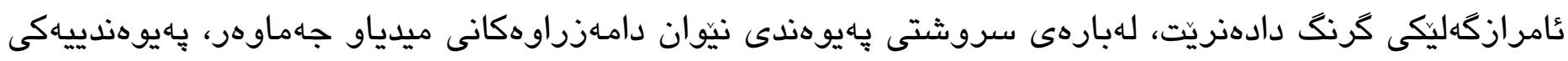

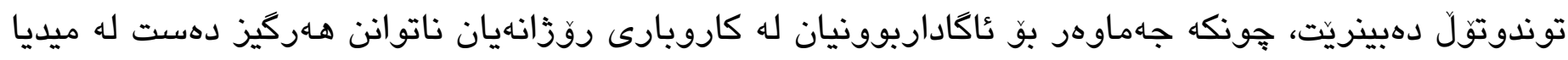

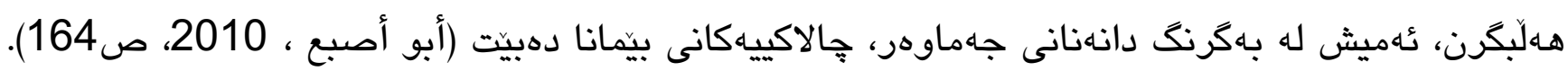

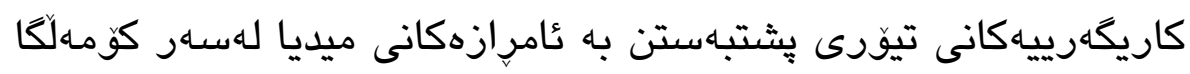

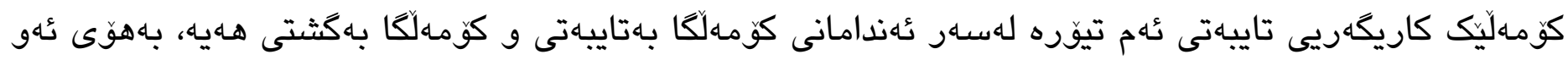

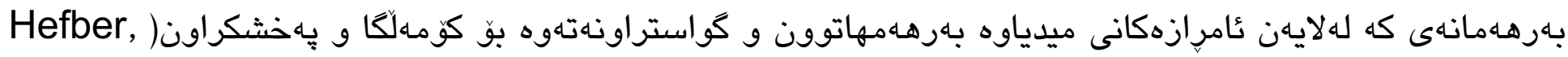

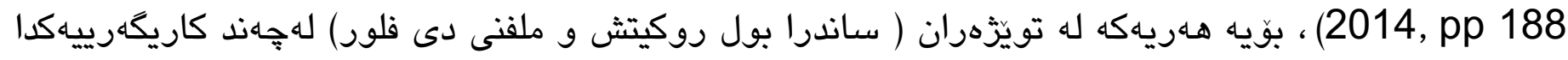

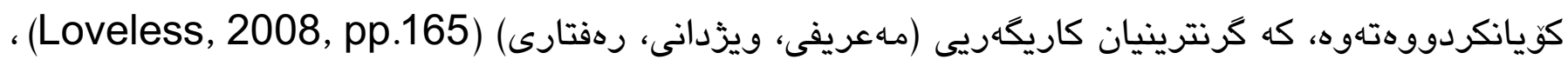
بهشيّوهيه دهيانخهينهروو:

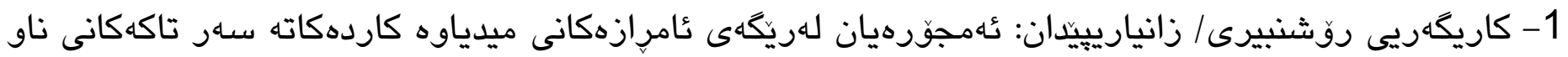

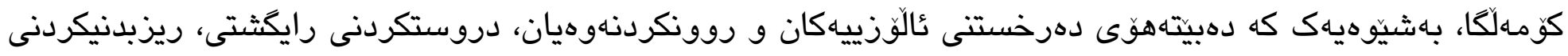

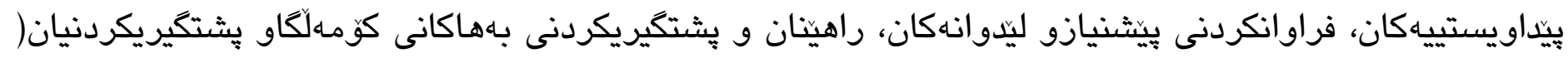
نهبي، 2016 2016 ئهنتهنيت). 


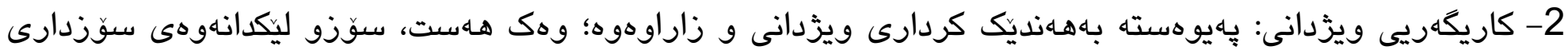

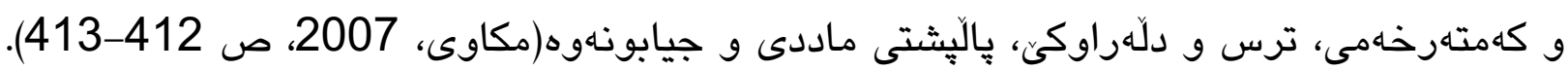

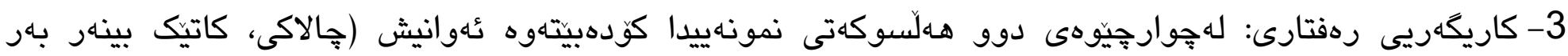

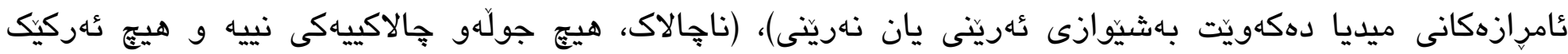

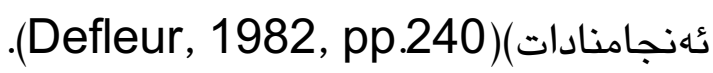

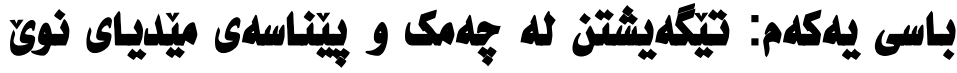

كَهشهاهندنى تهكنهلوزياى زانيارى و فراوانبوونى بهكارهينانى تؤرهكانى ئينتهرنيت سهارجهم كايهكانى زيانى

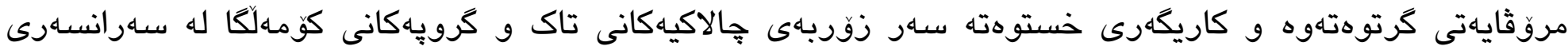

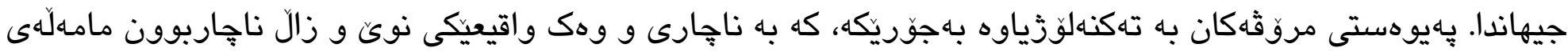

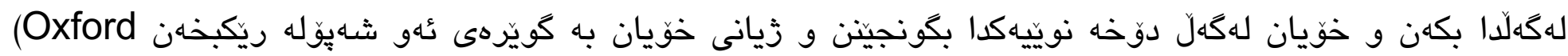
dictionary, 2018 )

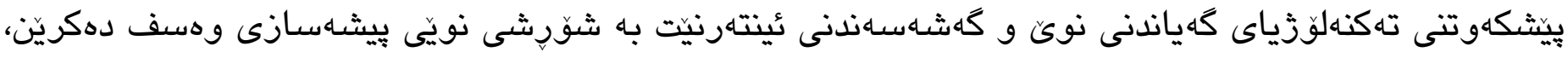

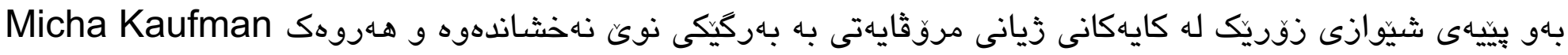

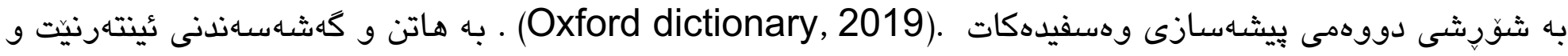
تهكنهلوزياى كهياندنى نوى، كايه زيارييهكانى وهك سياسى، ئابورى، كوّمهلايهتى، فهرهانكى و بوارهكانى ديكهش

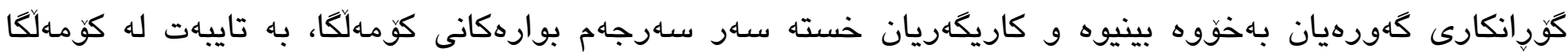

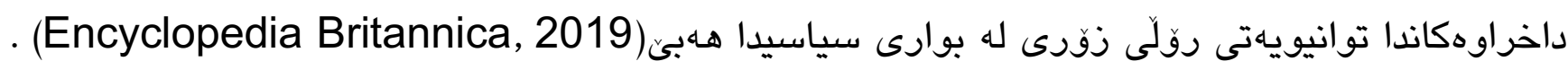

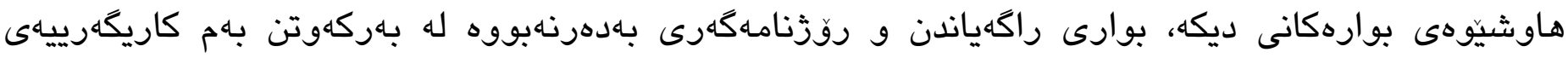

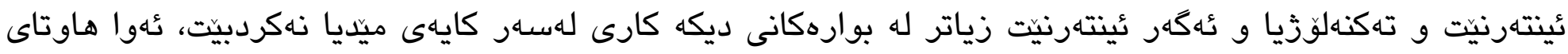

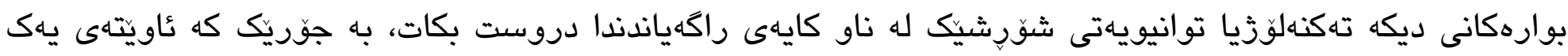

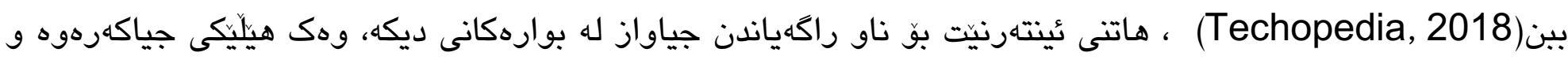

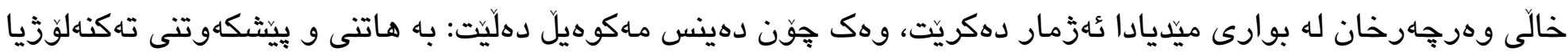

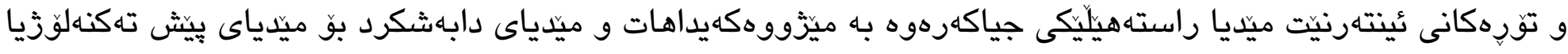

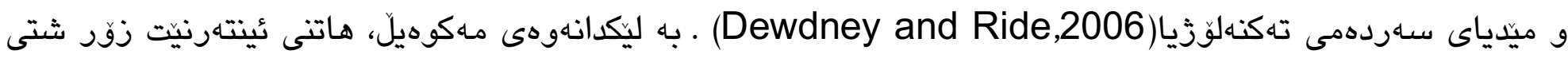

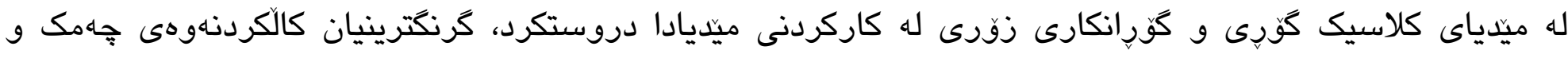

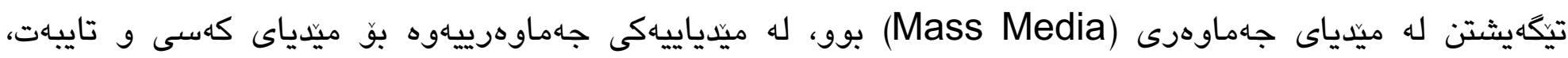




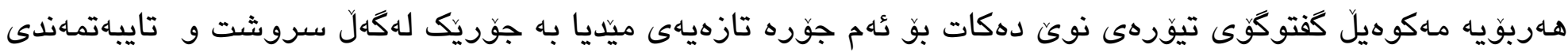
و شيّازى كاركردنيدا بكونجيت (Gibloa, 2005).

\section{بينّاسلهى ميّلياى ثوى:}

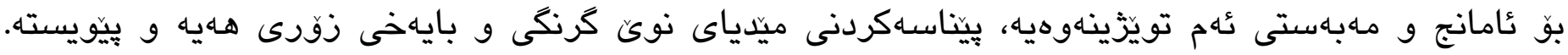

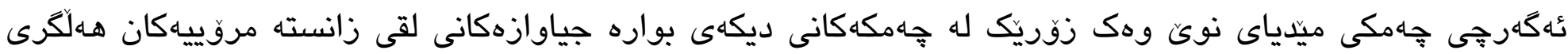

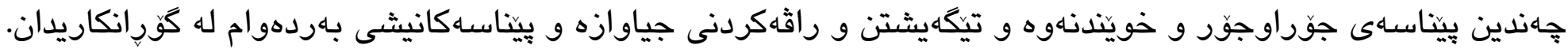

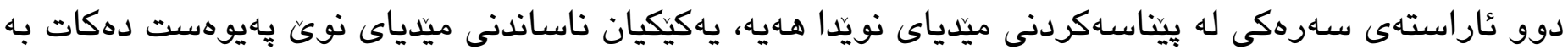
كؤمييوتهر و تهكنهوزياوه، كه ئهمهيان يهكانكير دهبيتهوه له تيكاهيشتنى زاناى بوارى كومونيكهيشن، مارشال ماكلوهان، كه لهسالانى شهستهكانى سهدهى رابردوودا عامرازى راكهياندن وهك جهاقى ميّديا تهماشـا دهكات و بِييوايه عُهوه عامرازه

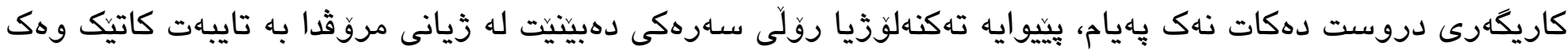
ميّدياى نويى خوى بهرجهاسته دهكات(

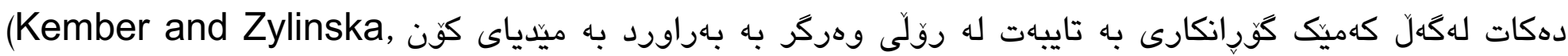

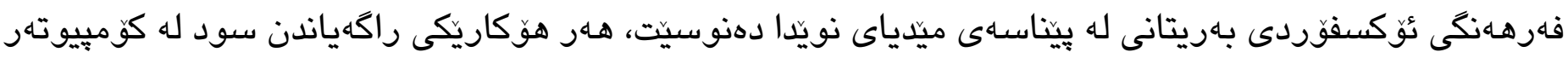

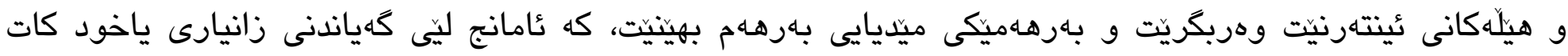

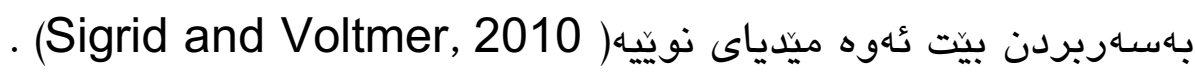

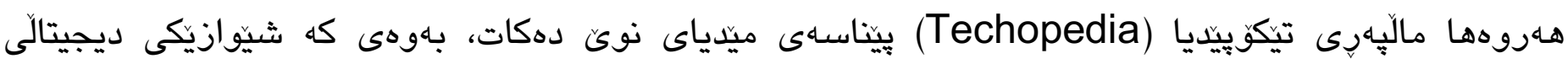

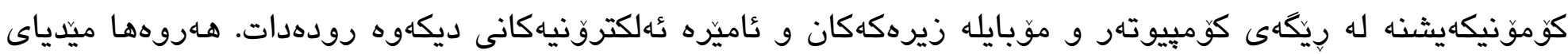

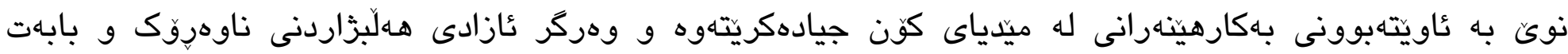

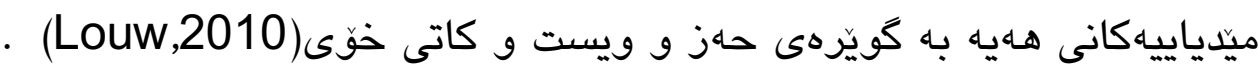

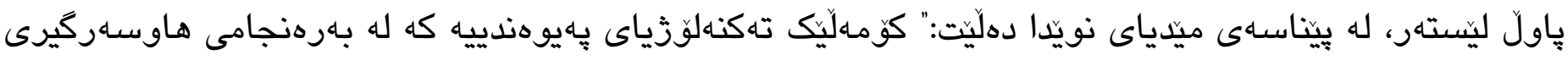

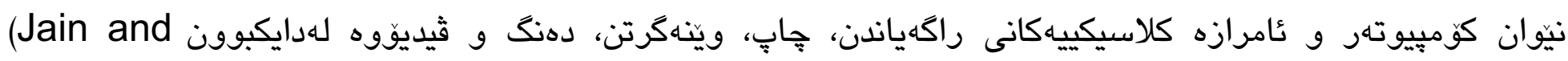
Zhang, 2012)

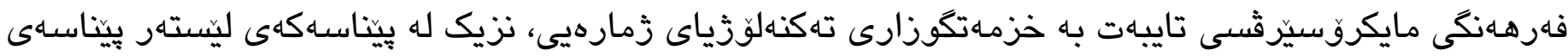

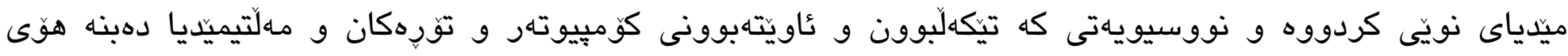

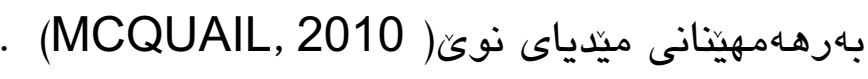




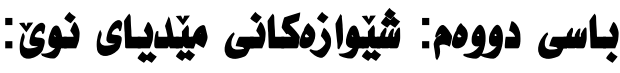

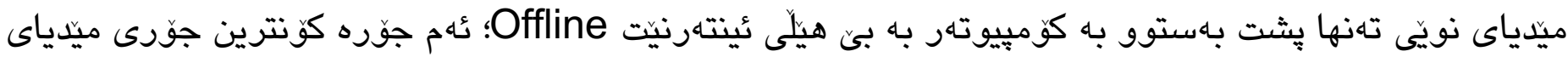

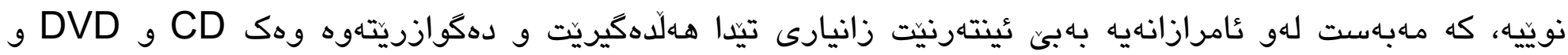
Hard Disk هيلّلى ئينتهرنيت سوديان ليّوهربكيريّت

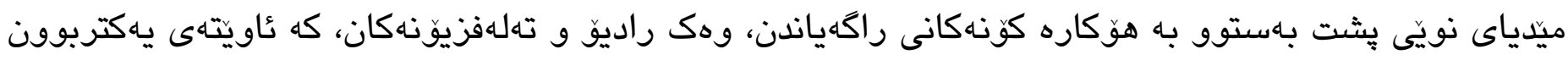
و جهاند سيفهتيك بو هوَكاره راكهياندنهكه زيادبووه، وهك كارليكردن و ديجيتاليبوون و وهلامدانهوه وهك ئهوهى له

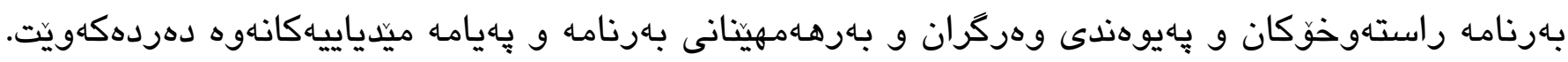

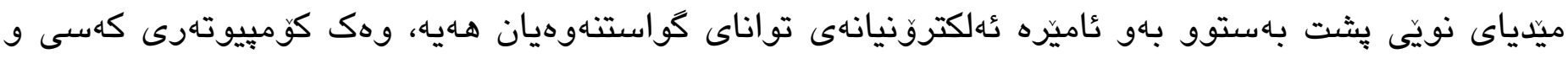

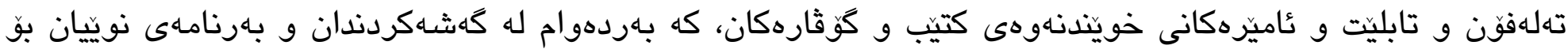
زياد دهبيت بوّ كارئاسانى.

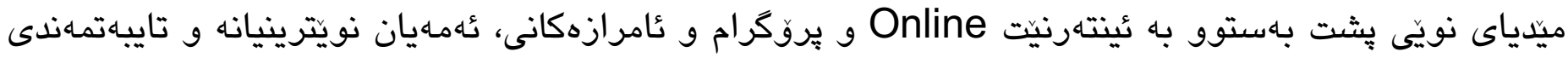

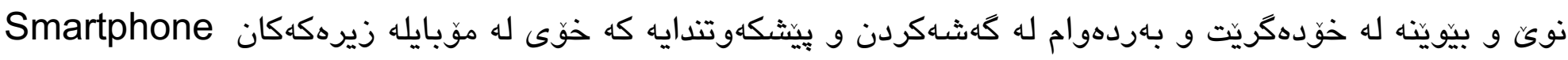

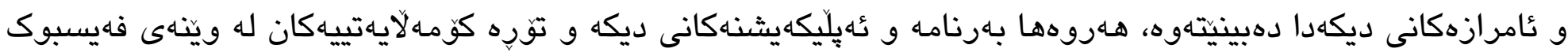

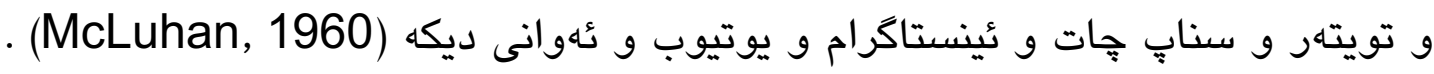

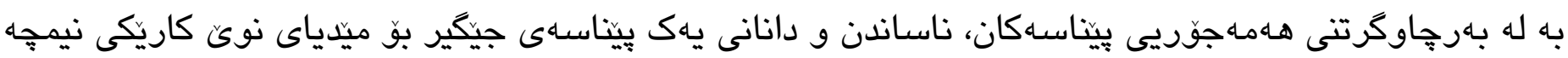

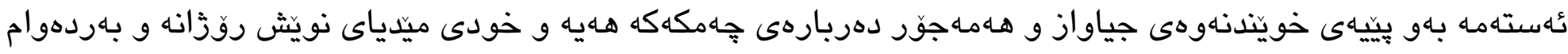

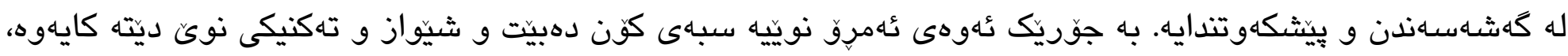

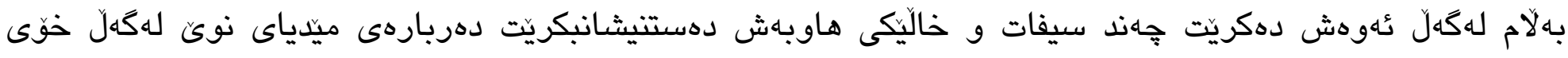

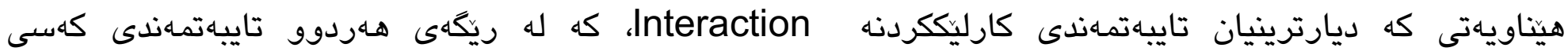
Individuality

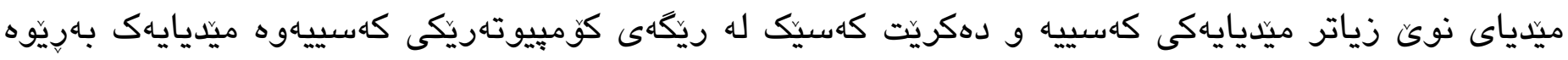

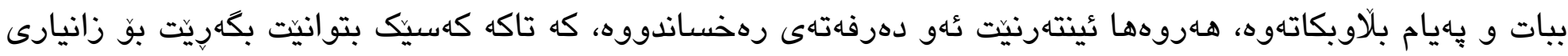

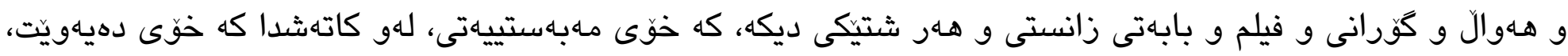

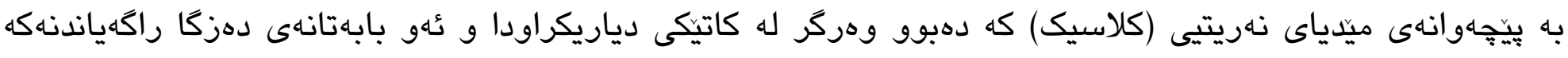

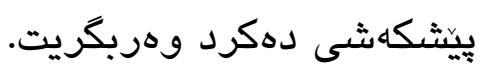




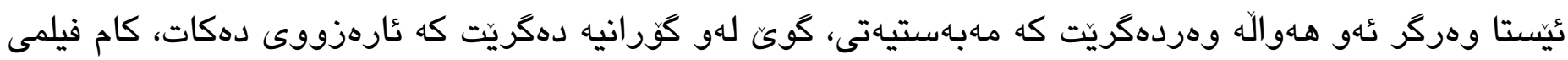
حهز لييّيت تهماشاى ئهوه دهكات. هـروهها خُوى بريار دهدات له ع كاتيدا و به ع شيّوازيك سهيرى بابهته ميّدياييهكان دهكات و لهوهش زياتر دهتوانيت دووباره ئهو بابهتانه بلاويكاتهوه و تهنانهت هـنديكجار خوّشى دهبيته بهرهامهينّهر و دروستكارى بابهت و هـوالةكان.

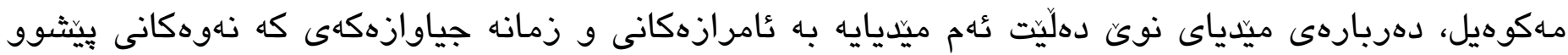

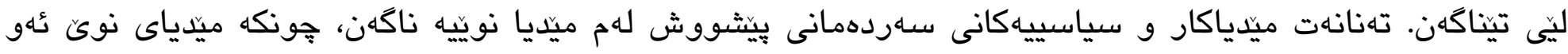

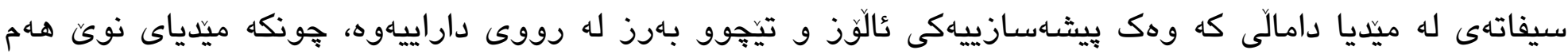

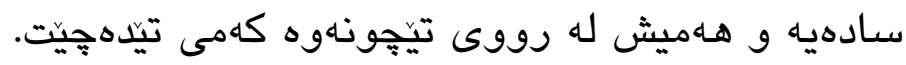

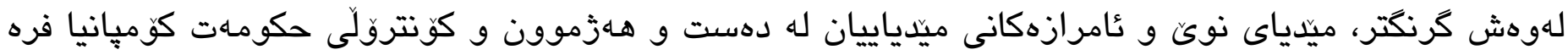
رهكهزكان سنوربرهكان دهرهينا. ئيتتهنيت بيروكهى سود و لوزيكى دهستبهسهراكرتن و كونتروّلكردنى ميدياى

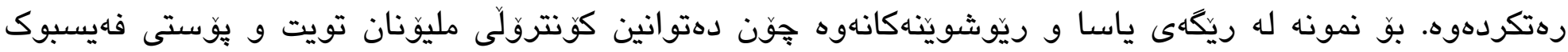
بكهين ؟

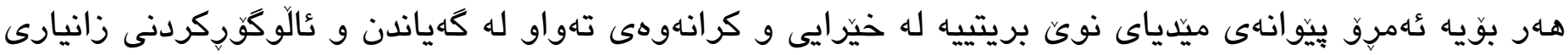

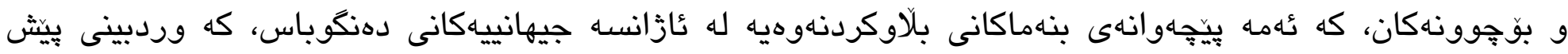

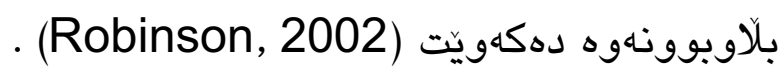

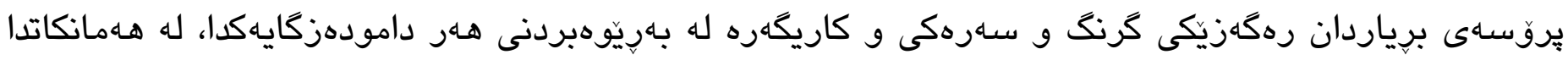

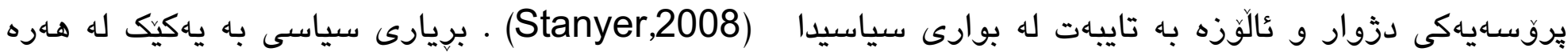

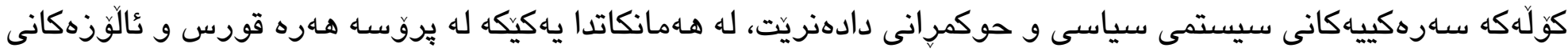

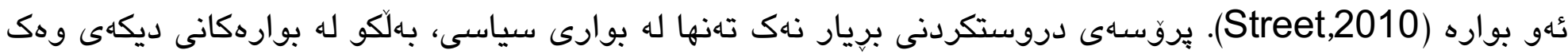

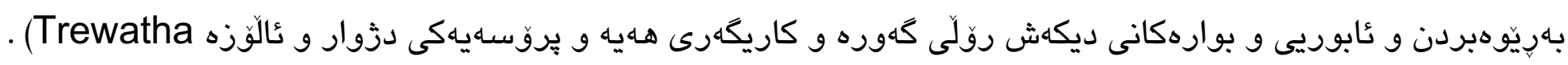
and Newport, 1982)

Trewatha \& Newport (2017) بهم شيّوهيه يِيناساهى بِروّساهى دروستكردنى بريار دهكهن، "دروستكردنى بريار هـلّزَاردنى باشترين بزاردهيه له نيّ دوو ياخود زياتر له بزاردهيهك له ييناو كهيشتن به جاردساهى كيشهيهك". له هـمانكاتدا فهرهـنكه عهرهبييهكان جههمكى دروستكردنى بريار له رووى زمانهوانييهوه پֶهيوهستدككهن به بوارى

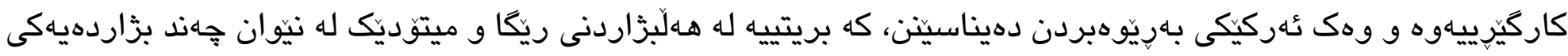

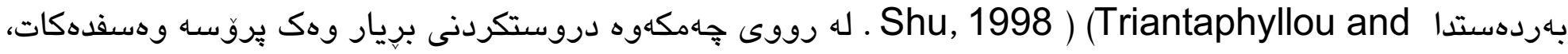

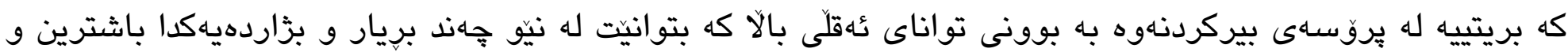




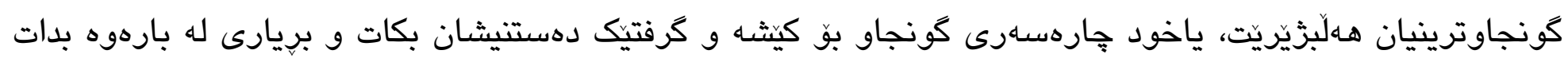
.(Harris, 2019)

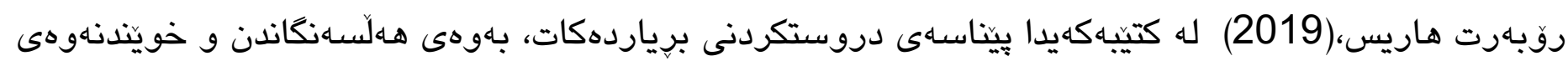

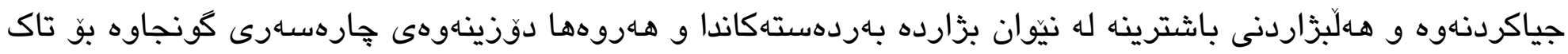

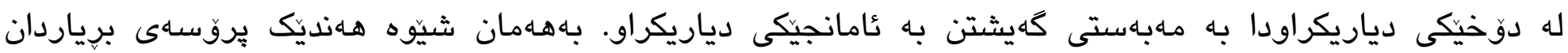

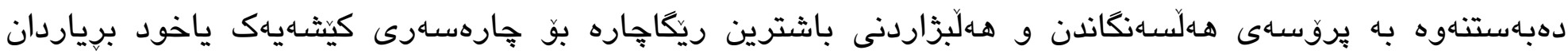

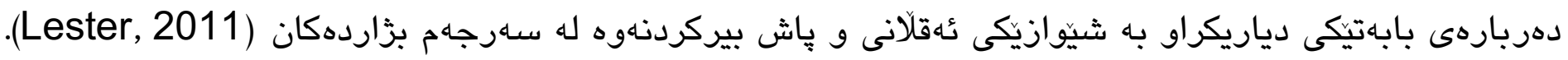

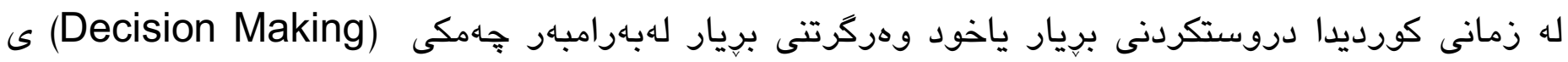

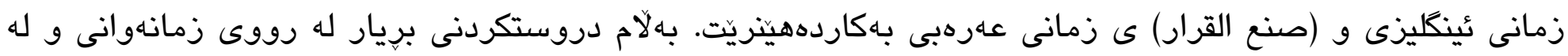

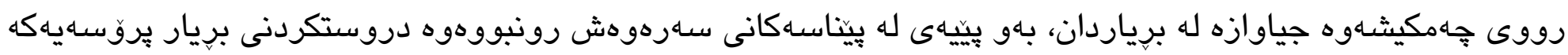

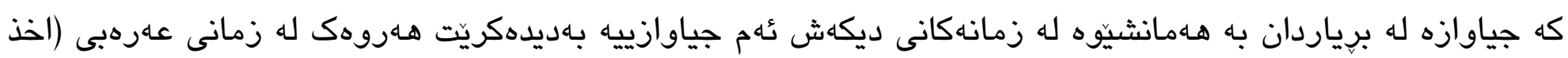

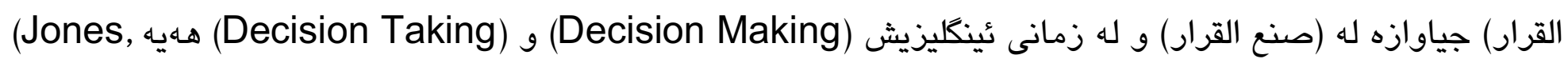

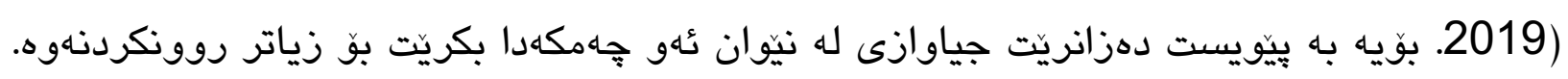

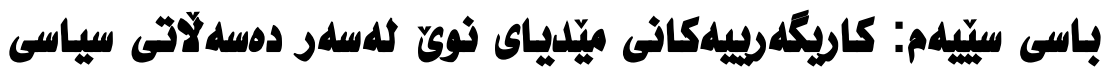

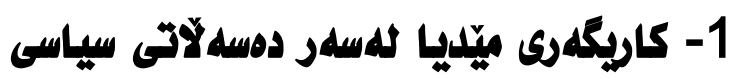

بهناويانكترين نمونهى كاريكهرى ميدّيا لهسهر برياربهدهستانى سياسى ئهوهيه كه به

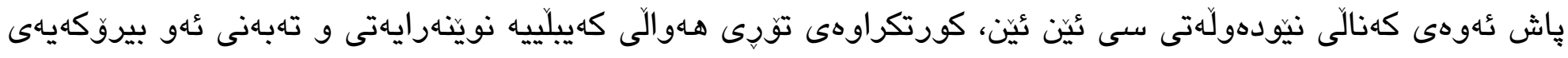

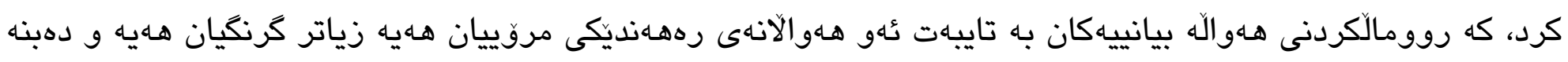

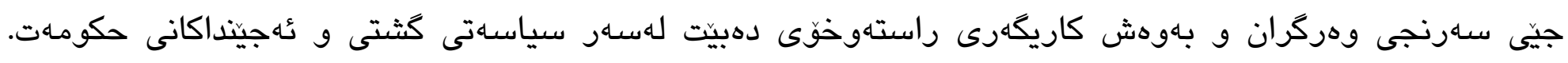

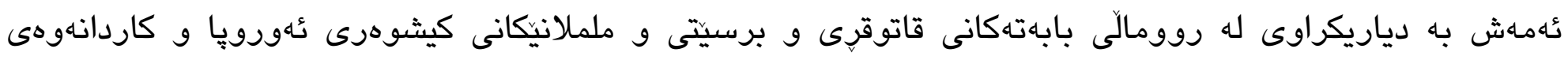

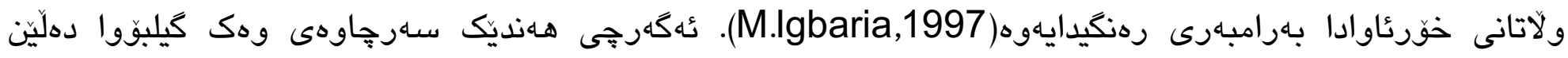

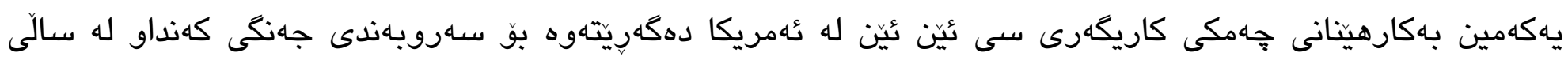

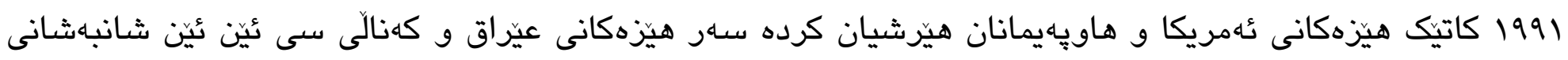

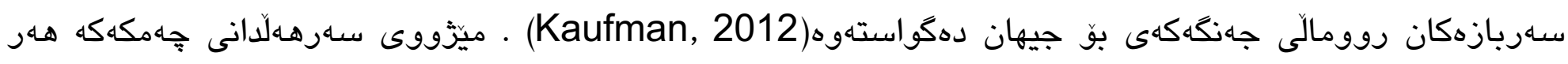

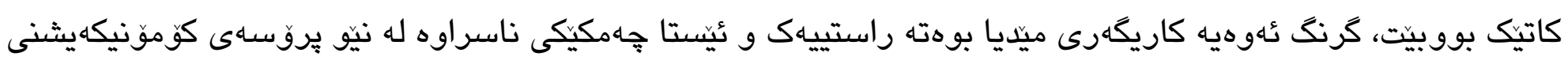

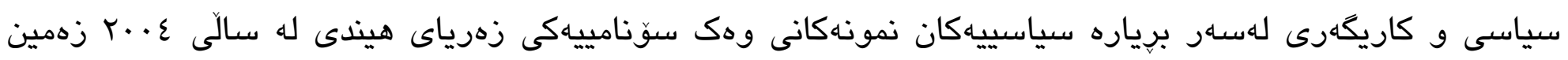




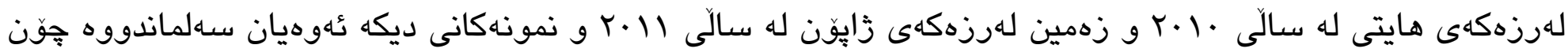

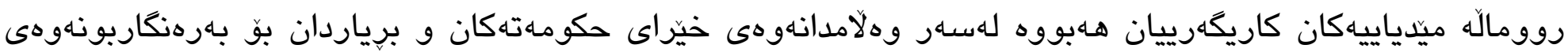

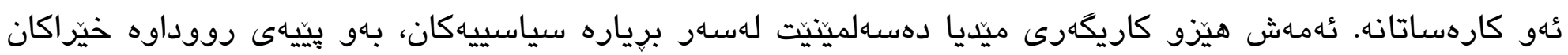

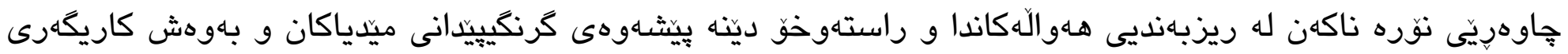

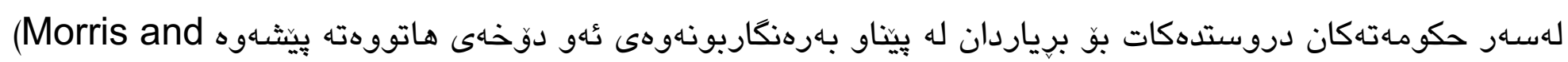

.Ogan, 1996 )

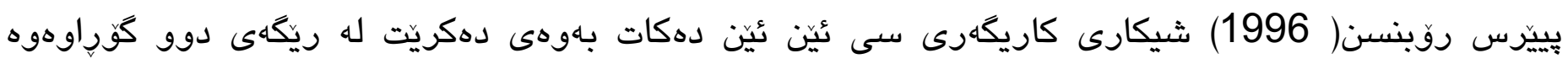

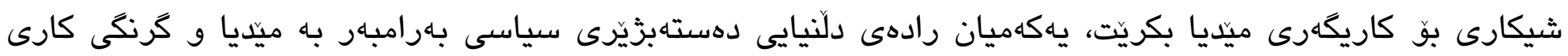

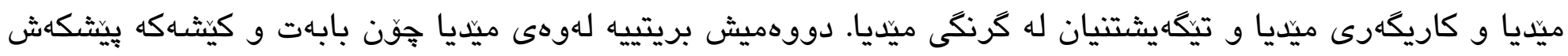

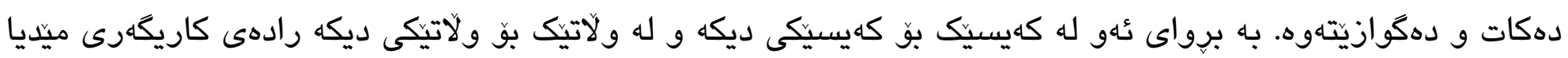

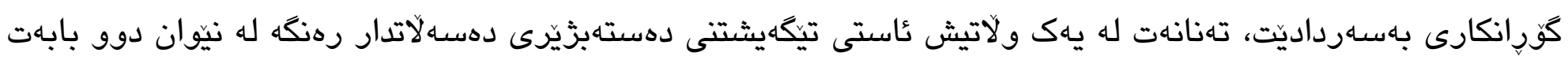
و كيتشهدا جياواز بيت.

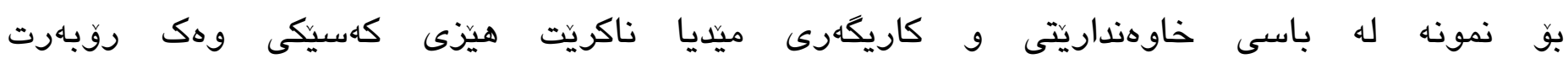

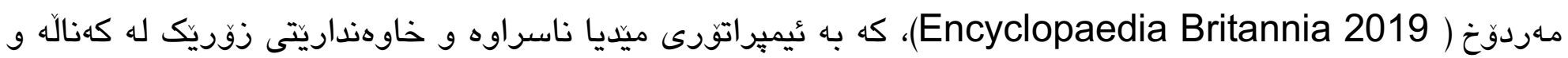

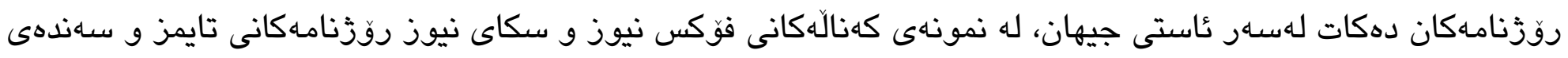

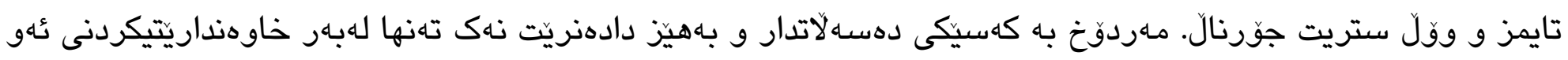

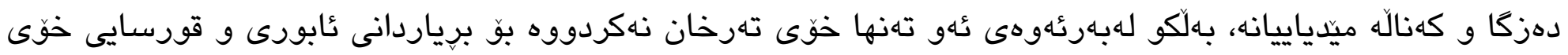

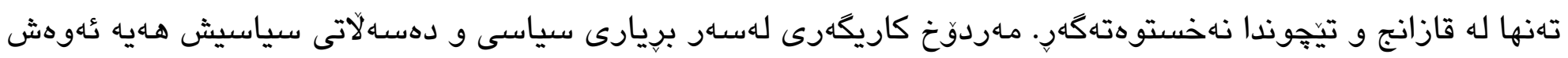

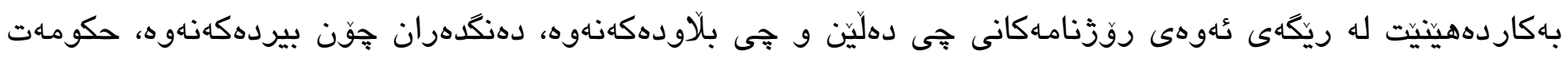

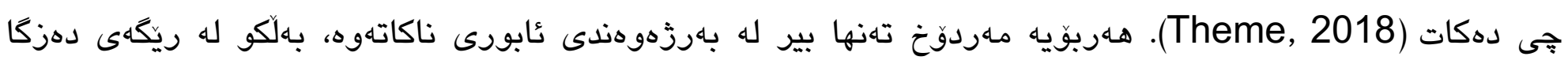

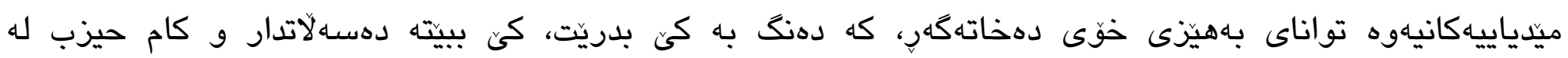

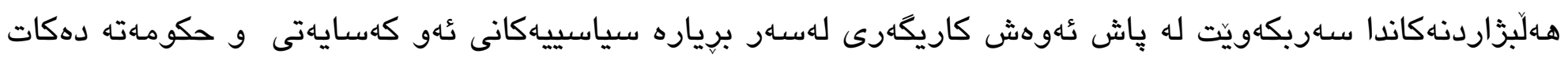

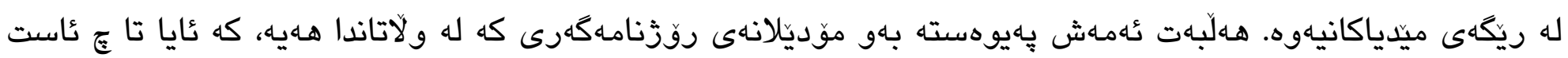

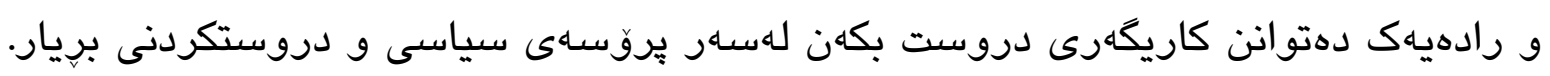




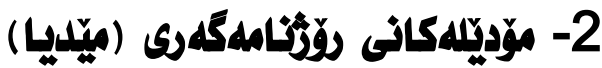

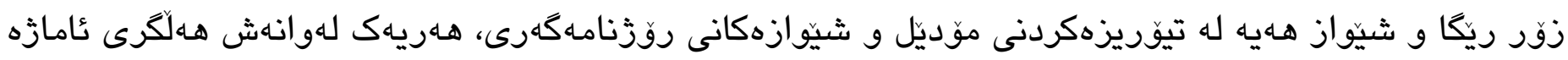

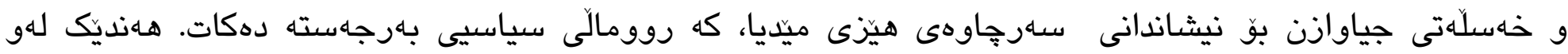
مؤديالانى رؤنامهكهرى كاريكهرى زور خيّرا دروستدهكن، ههنديكى ديكهيان هيج كاريكهرى دروست ناكهن. به

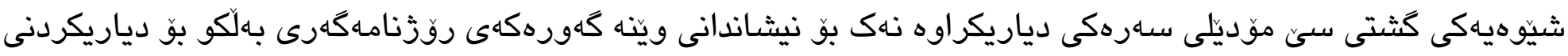

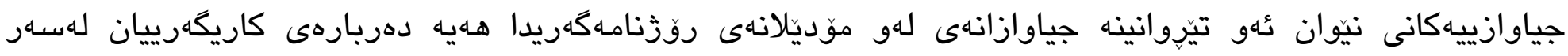
سياسهات به شيّوهيهكى كَثتى بهمشيّوهيه:

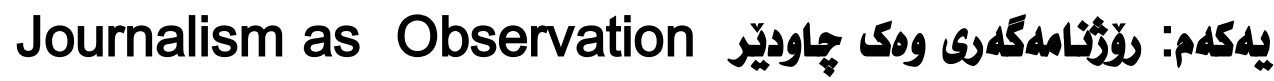

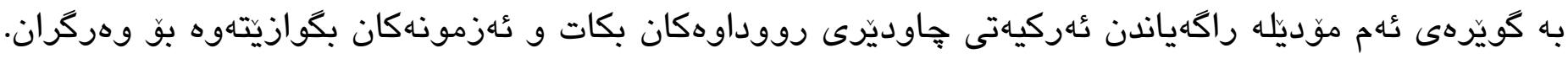

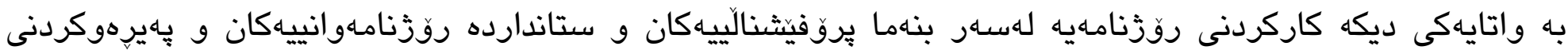

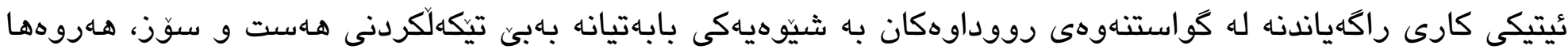

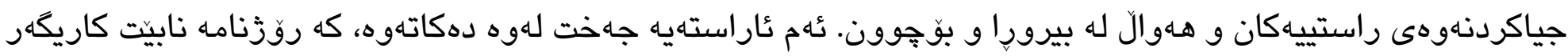

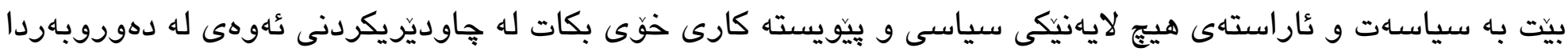

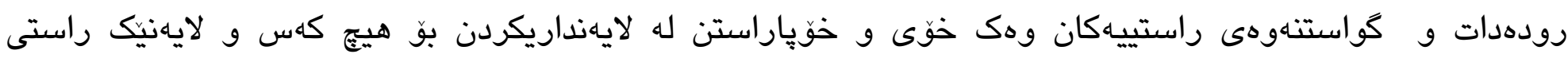
رووداوهكان ناهييت.

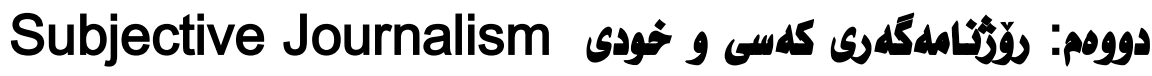

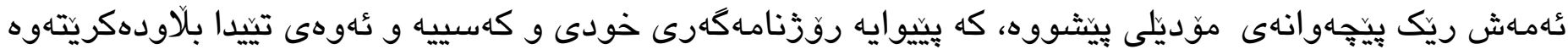

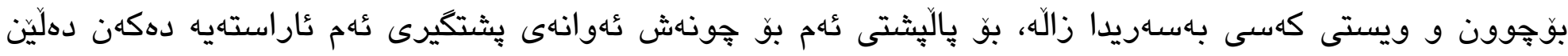

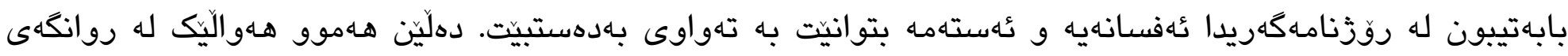

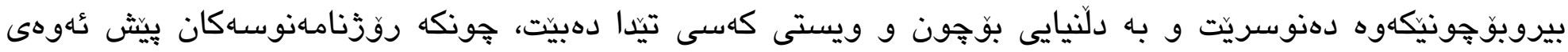

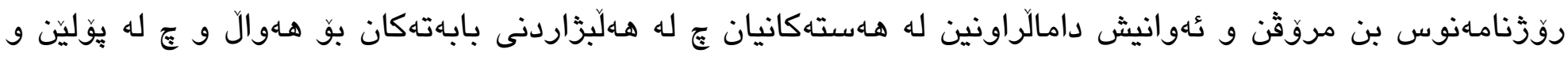

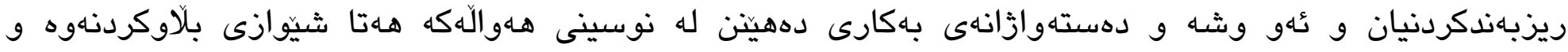

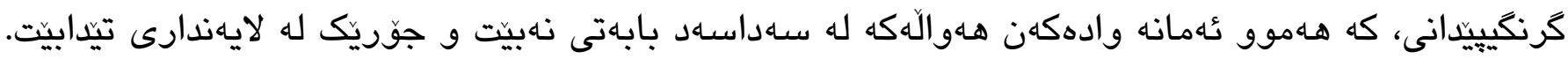




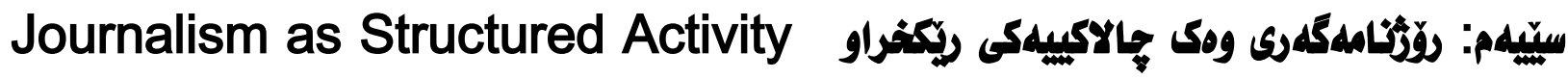

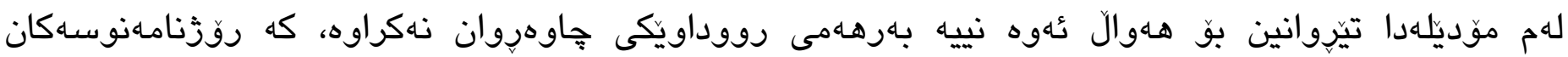

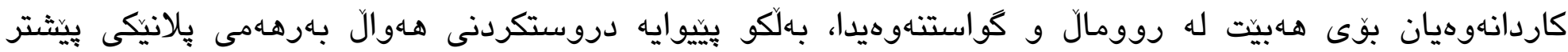

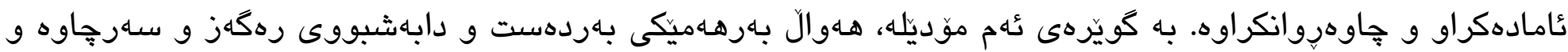

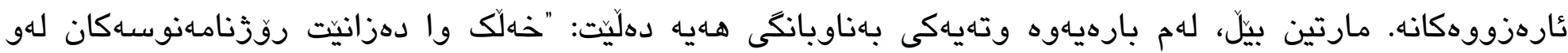

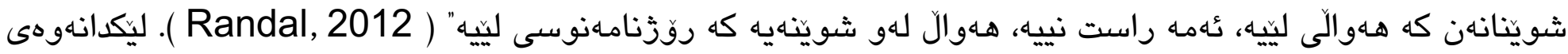

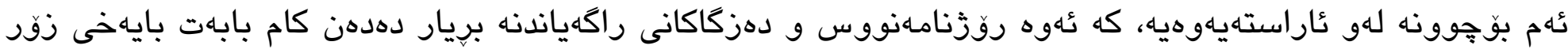

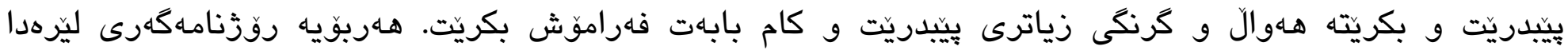

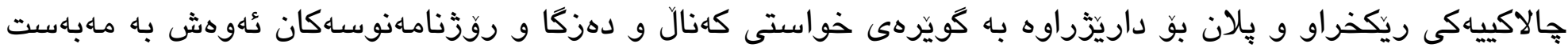

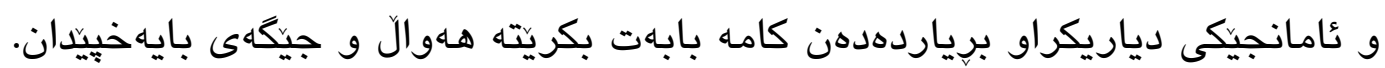

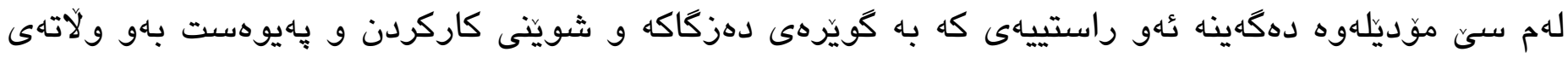

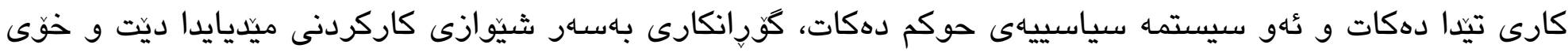

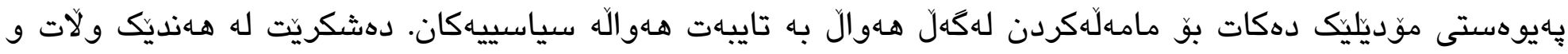

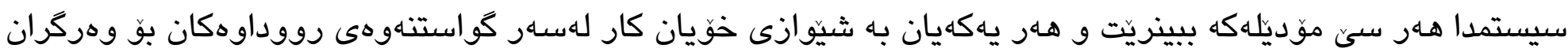

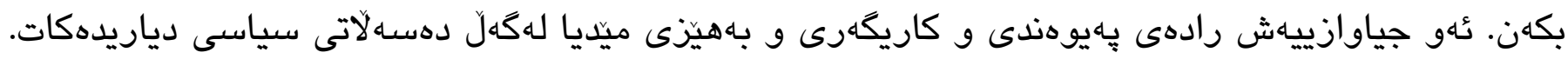

\section{باسى جهوارهم: لايهنى مليدانى تويَّرينهوه}

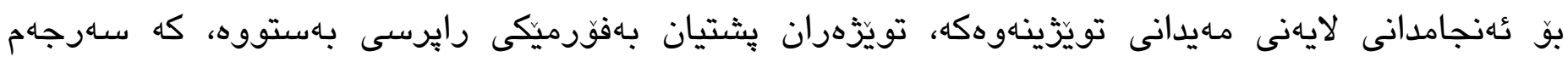
بهارلهمانتارانى كوردستان وهكو سامبِل وهركيراون. راستى فورمى دووييّوى

\section{هاساومكانى دياريكردنى ساميلّ:}

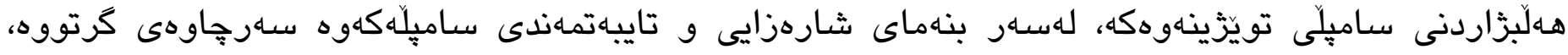

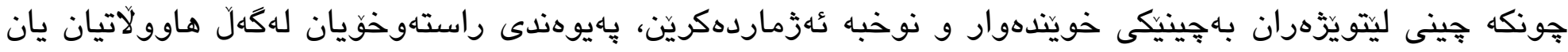

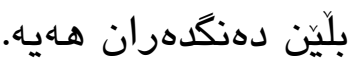

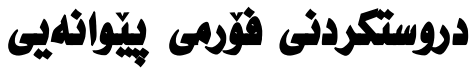

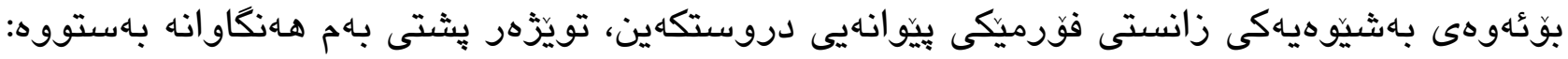

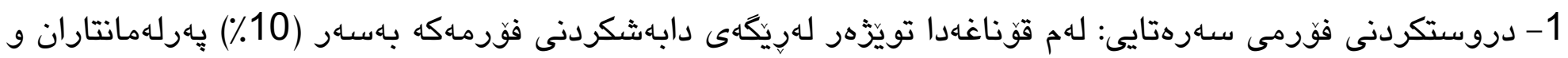

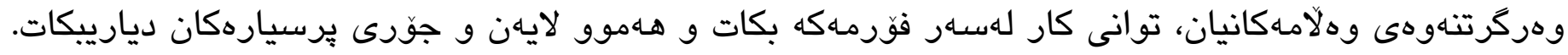




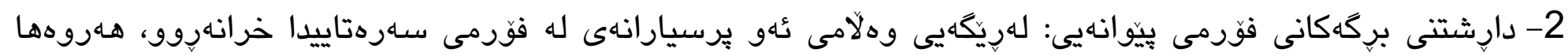

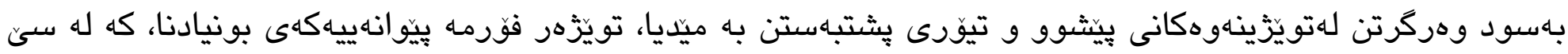

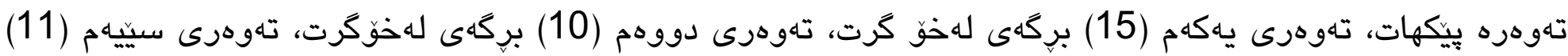

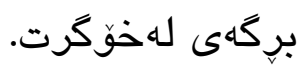

\section{راستى فؤرمى دووبيِّوى}

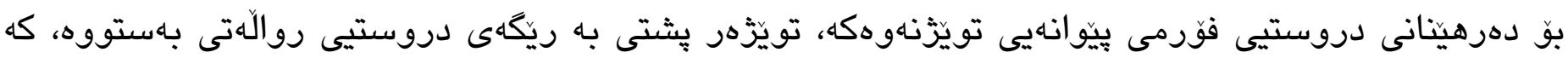

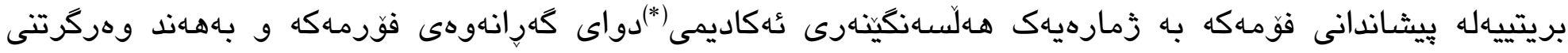

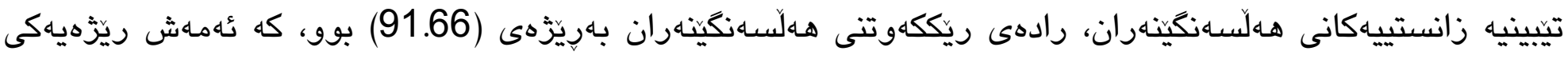
كونجاوه لهرووى زانستييهوه.

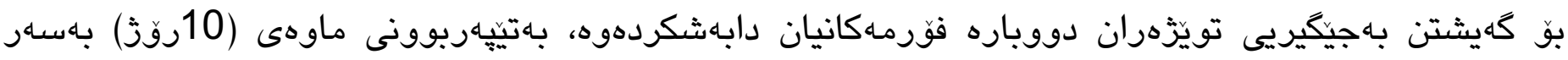

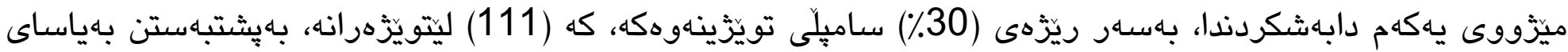

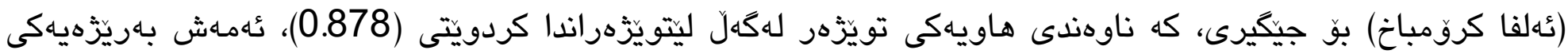

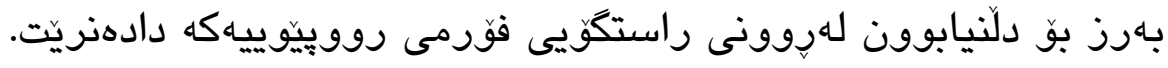

\section{لايلهذى مهيداثى تملئزينهوه}

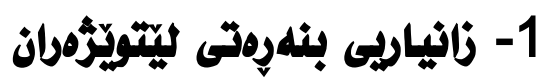

دواى هـلاّويَركردنى زانياريييه بنهرهتييهكانى تاييهت به ليتويّزهران، دهردهكهويت له رِووى (رهكهزهوه)، ساميلّى

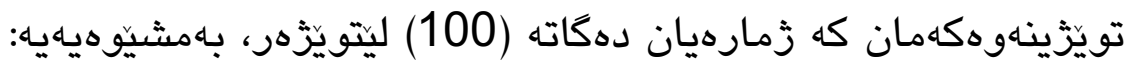

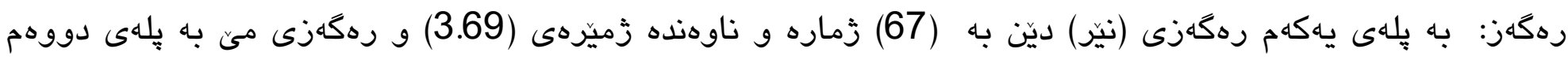

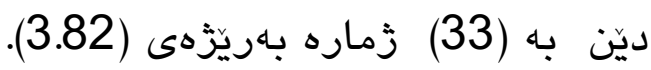

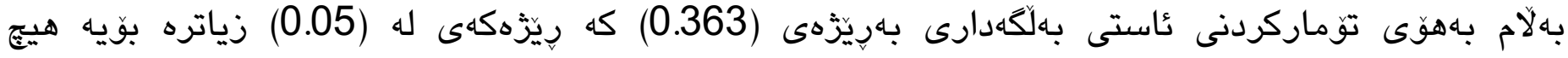

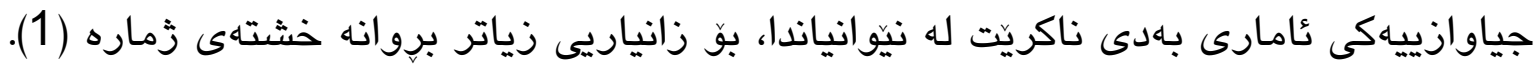

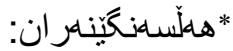

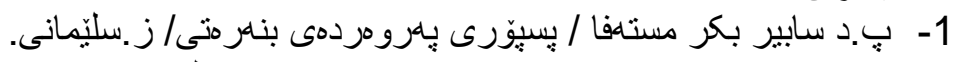

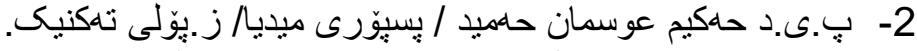

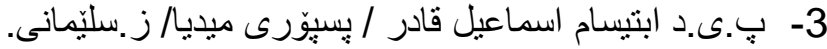


خشتهى (1)

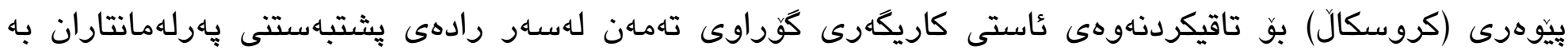
ميّدياى نويى

\begin{tabular}{|c|c|c|c|c|c|c|}
\hline بهاى Tهاي & 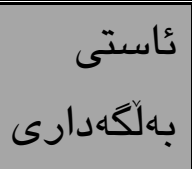 & نمازادى نمى & لادانى يَّوهرى & ثَاوهنده & j & رهكَز \\
\hline \multirow{2}{*}{0.914} & \multirow{2}{*}{0.363} & \multirow{2}{*}{98} & 0.908 & 3.69 & 67 & نيزير \\
\hline & & & 0.528 & 3.82 & 33 & مئى \\
\hline
\end{tabular}

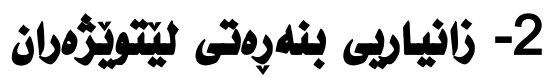

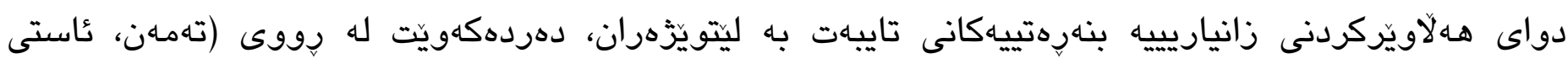

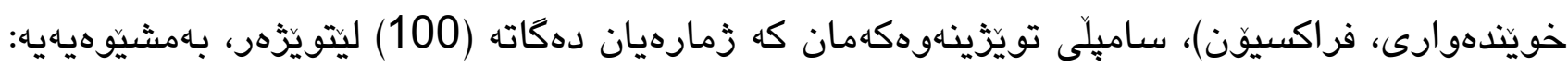

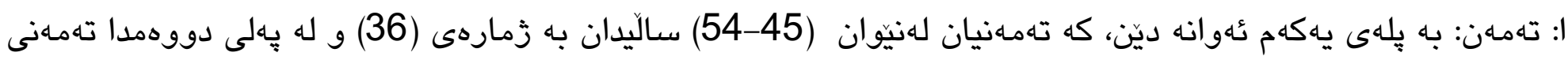

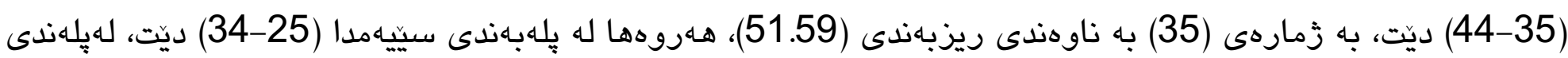

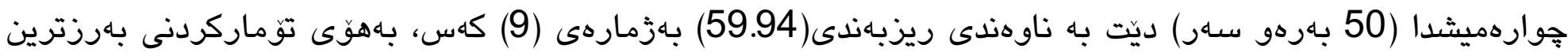

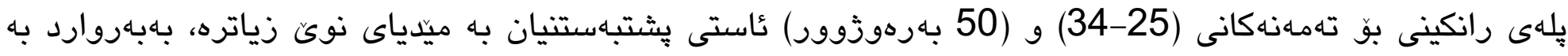
تهمهنهاكانى تر.

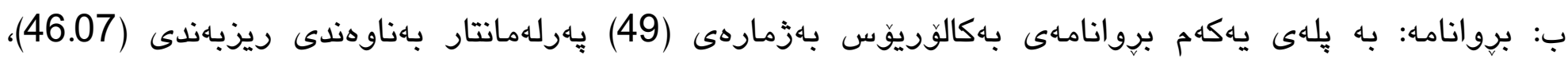

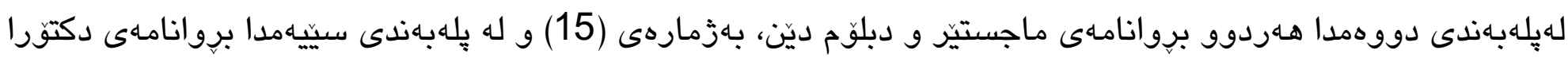

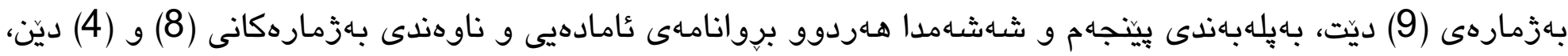

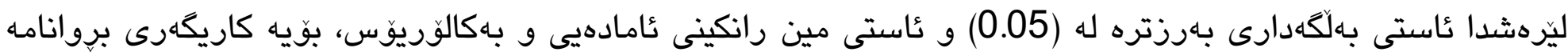

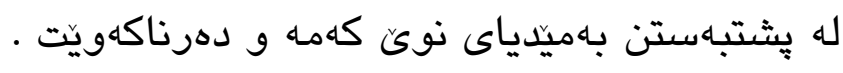

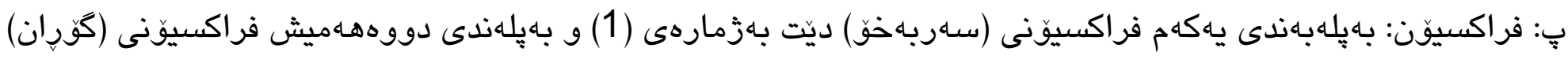

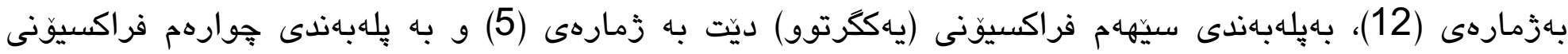

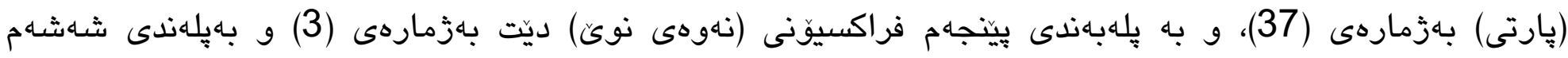

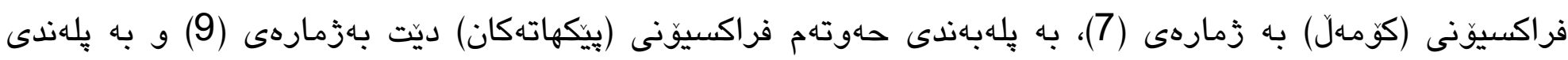

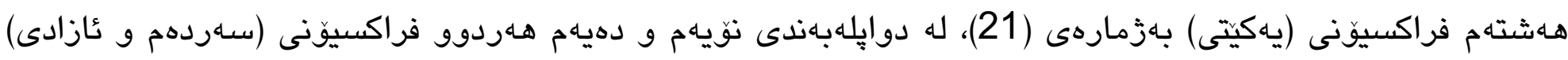

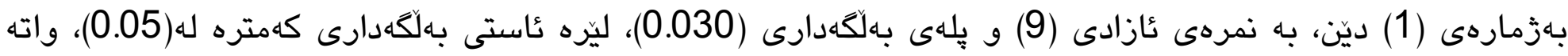


جياوازى هـهيه و لهسهر ئاستى فراكسيوّن و رادهى بشت بهستنى بِهرلهمانتاران به ميّدياى نوىّ و مين رانكى سهربهخو

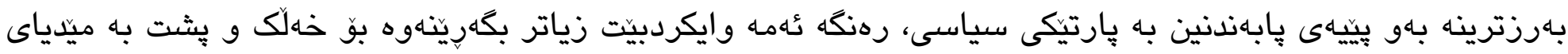

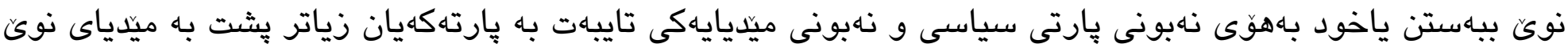

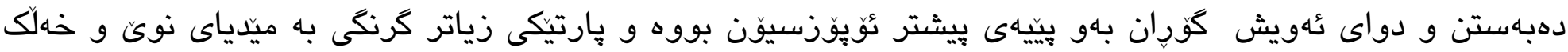

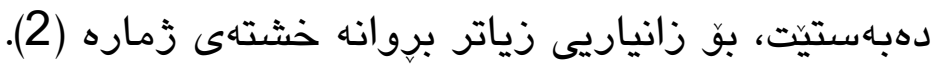

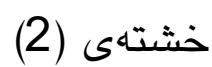

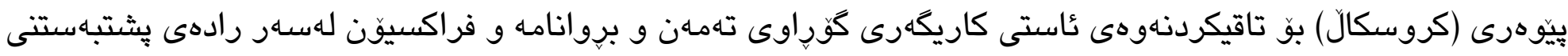

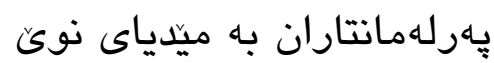

\begin{tabular}{|c|c|c|c|c|c|c|}
\hline 215 & بـاستَّى & نمازادىى & ئاست & ناوهنديريزبهندى & $\bar{j}$ & ت تهمهن \\
\hline \multirow{4}{*}{2.024} & \multirow{4}{*}{0.567} & \multirow{4}{*}{3} & 1 & 46.07 & 36 & 54-45 \\
\hline & & & 2 & 51.59 & 35 & $44-35$ \\
\hline & & & 3 & 55.03 & 20 & $34-25$ \\
\hline & & & 4 & 53.94 & $\overline{99}$ & -55 \\
\hline 215 & 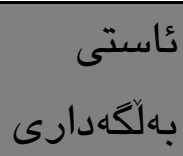 & نمازادى نمرهى & عاست & ناوهنديريزبهندى & $\bar{j}$ & بروانامه \\
\hline \multirow[t]{7}{*}{5.814} & 0.325 & 5 & 1 & 4352. & 49 & بهكالوريوّس \\
\hline & & & 2 & 48.83 & 15 & ماجستيزر \\
\hline & & & 2 & 3340. & 15 & دبلوم \\
\hline & & & 3 & 4454. & 9 & دكتورا \\
\hline & & & 4 & 62.44 & 8 & ئامادهيى \\
\hline & & & 5 & 5038. & 4 & ناوهندى \\
\hline & & & 6 & - & - & ساهرهتايى \\
\hline
\end{tabular}




\begin{tabular}{|c|c|c|c|c|c|c|}
\hline 215 & باساستى بكاردارى & |نمازادى & يلهبهندى & ناوهنديريزبهندى & $\dot{j}$ & فراكسيّن \\
\hline \multirow{10}{*}{18.445} & \multirow{10}{*}{0.030} & \multirow{10}{*}{9} & 1 & 68.13 & 4 & ســربهاهو \\
\hline & & & 2 & 61.29 & 12 & كَّرِان \\
\hline & & & 3 & 59.00 & 5 & يهكگرتوو \\
\hline & & & 4 & 55.43 & 37 & 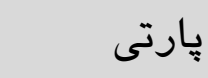 \\
\hline & & & 5 & 53.33 & 3 & نهوهى نوكى \\
\hline & & & 6 & 53.14 & 7 & كوّمهل \\
\hline & & & 7 & 43.44 & 9 & يِيكهاتهكان \\
\hline & & & 8 & 35.10 & 21 & يهكيتى \\
\hline & & & 9 & 18.00 & 1 & سلهردهم \\
\hline & & & 9 & 18.00 & 1 & ئازادى \\
\hline
\end{tabular}

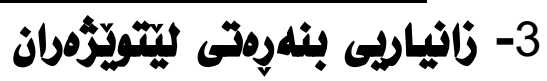

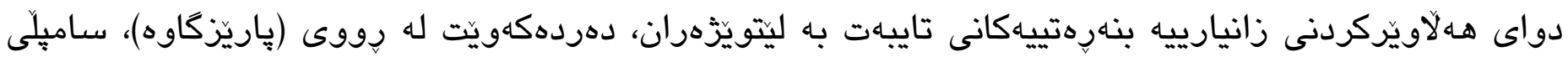

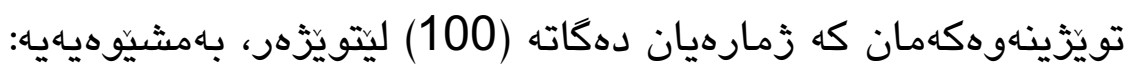

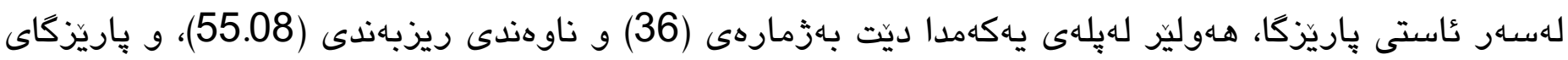

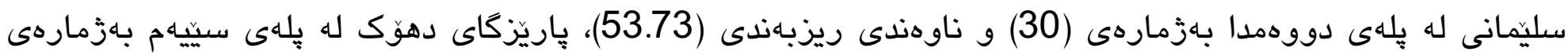

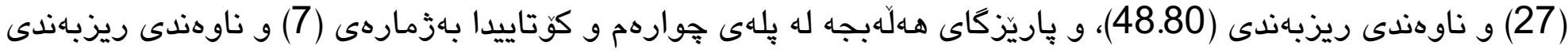

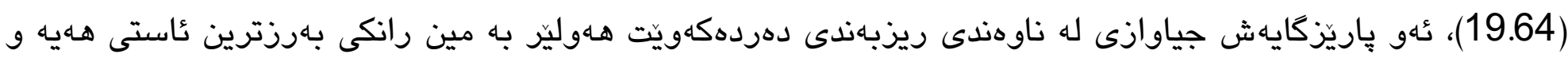

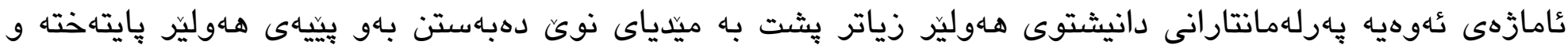

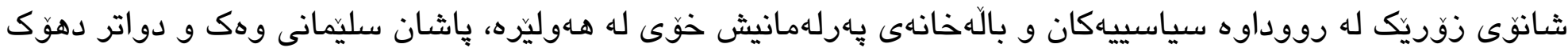

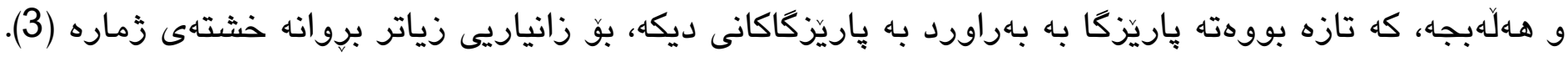


خشتهى (3)

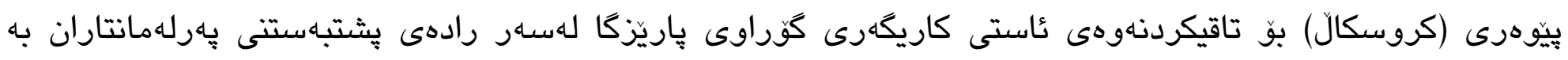

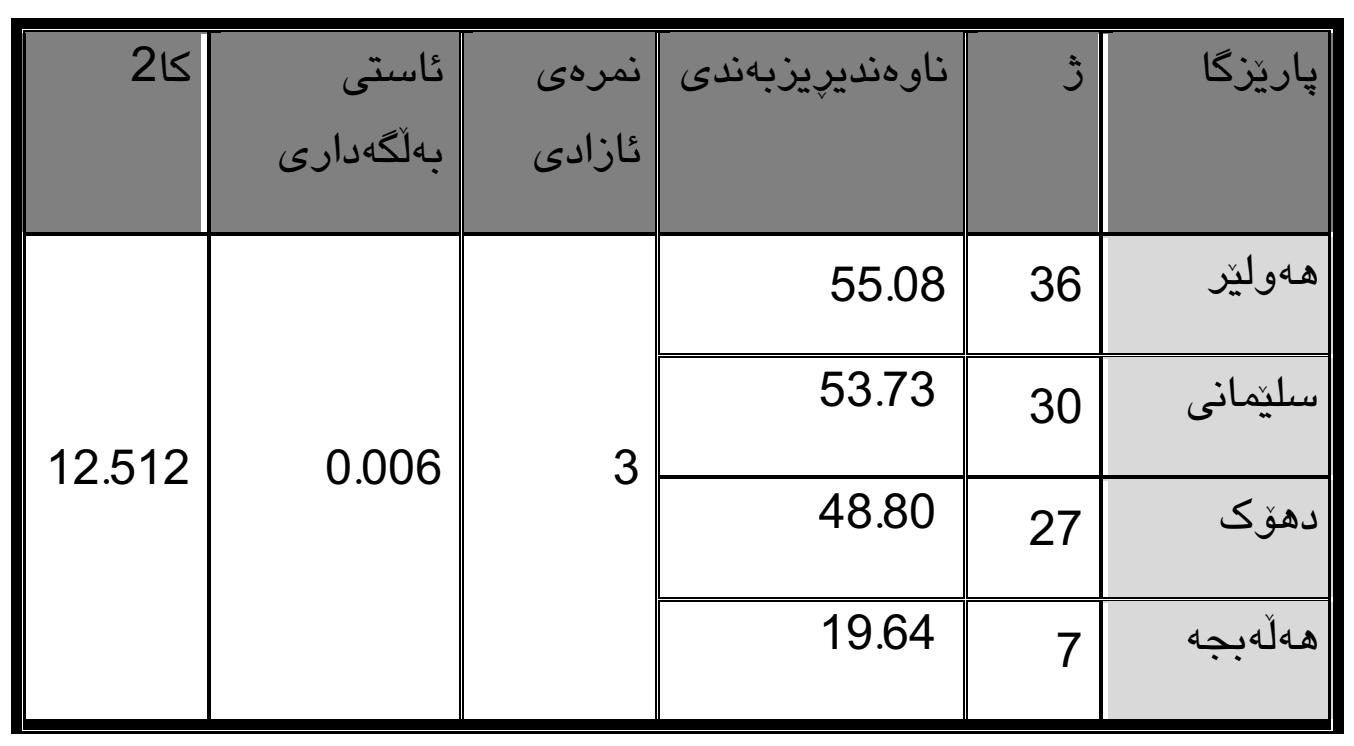
ميّدياى نويى

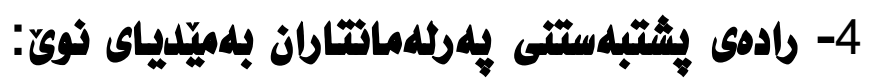

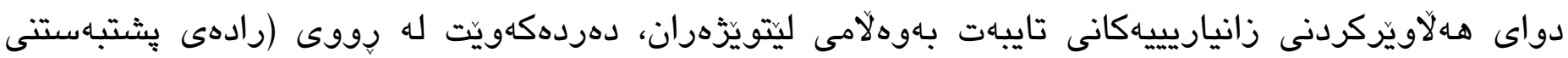

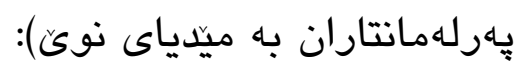

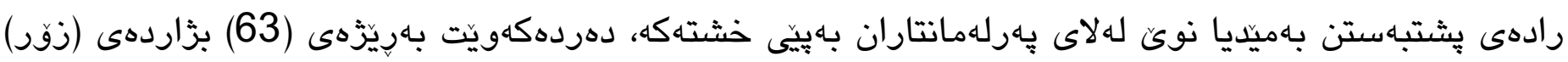

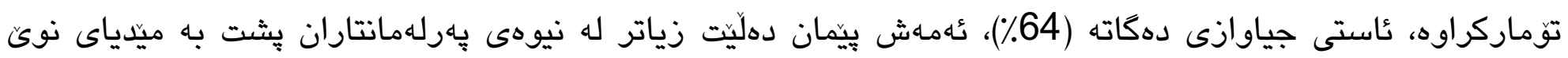

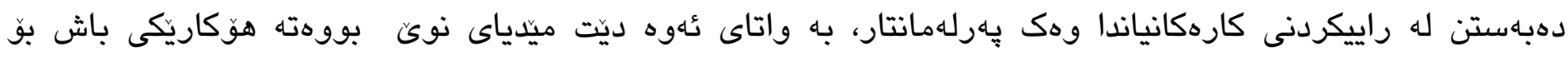

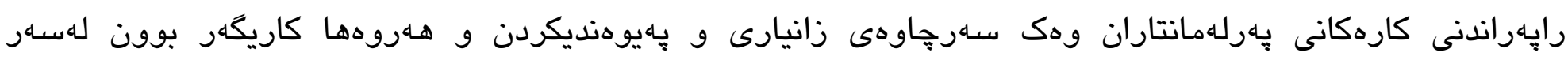

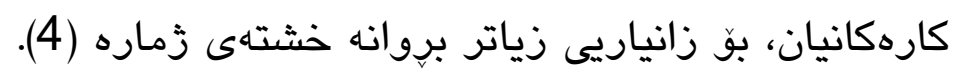


ثاستى كاريكهرى ميّدياى نوىّ له كاريكَرى خستنهسهر زانيارييهكانى بهرلهمانتاران

\begin{tabular}{|c|c|c|c|c|c|c|c|c|c|c|c|c|c|}
\hline \multirow[b]{2}{*}{$\sum_{n}^{\prime}$} & \multirow{2}{*}{$\begin{array}{l}a \\
t \\
\hat{E} \\
\hat{E}\end{array}$} & \multirow[b]{2}{*}{ c. } & \multicolumn{2}{|c|}{$\begin{array}{l}\underbrace{}_{\hat{L}} \\
\hat{b}\end{array}$} & \multicolumn{2}{|c|}{$\hat{\hat{A}}$} & \multicolumn{2}{|c|}{$\begin{array}{cc}c \\
. \bar{b} \\
\end{array}$} & \multicolumn{2}{|c|}{6} & & \multirow[b]{3}{*}{ 1. 1.ميّاياى نويَ وا دهكات ناكاداربم له هـوال } \\
\hline & & & $\%$ & $\Xi$ & $\%$ & 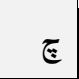 & $\%$ & छ & $\%$ & 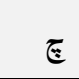 & $\%$ & 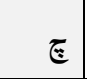 & \\
\hline زوّد & 1 & 3.86 & 0 & - & 5 & 5 & 24 & 24 & 51 & 51 & 20 & 20 & \\
\hline زود & 2 & 3.55 & 3 & 3 & 6 & 6 & 31 & 31 & 53 & 53 & 7 & 7 & 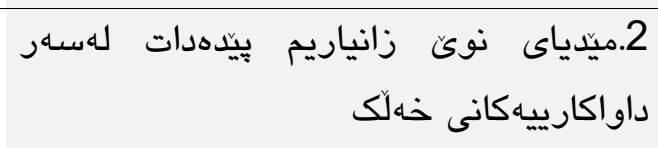 \\
\hline زؤ & 3 & 3.53 & 0 & - & 10 & 10 & 35 & 35 & 47 & 47 & 8 & 8 & 3.ميدّياى نوكن وادهكات زانيارييهكانم لهسهر \\
\hline زوّد & 4 & 3.40 & 3 & 3 & 16 & 16 & 29 & 29 & 42 & 42 & 10 & 10 & 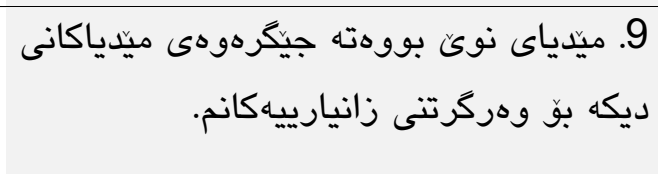 \\
\hline بيّلايهن & 5 & 3.18 & 7 & 7 & 16 & 16 & 35 & 35 & 36 & 36 & 6 & 6 & 7. ميندياى نوكن كارئاسانى دهكات زياتر \\
\hline بيّالايهن & 6 & 3.16 & 7 & 7 & 19 & 19 & 28 & 28 & 43 & 43 & 3 & 3 & 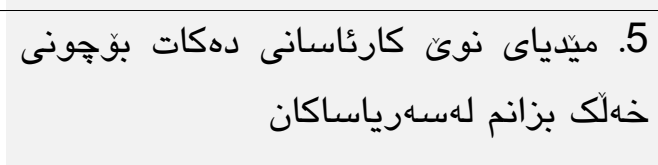 \\
\hline بيّلايهن & 7 & 3.15 & 10 & 10 & 12 & 12 & 37 & 37 & 35 & 35 & 6 & 6 & 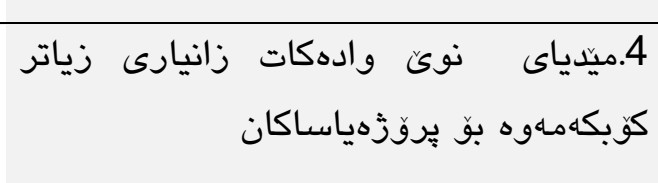 \\
\hline بيّلايهن & 8 & 3.14 & 9 & 9 & 20 & 20 & 30 & 30 & 30 & 30 & 11 & 11 & 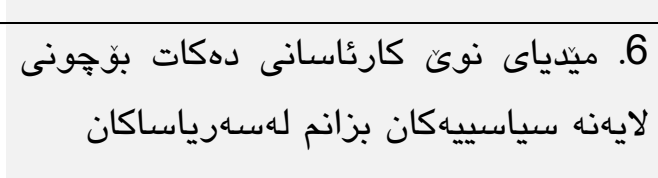 \\
\hline بيّلايهن & 9 & 3.07 & 3 & 3 & 20 & 20 & 49 & 49 & 23 & 23 & 5 & 5 & 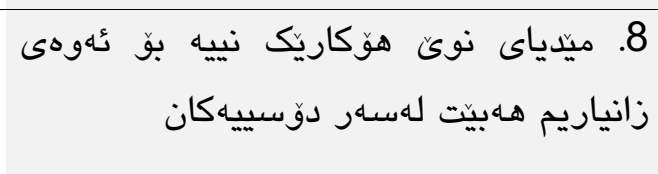 \\
\hline & بيَلاب & 3.33 & & & & & & & & & & & كوى كثتى \\
\hline & 27 & يمانه & & & & & & & & & & & 5 نمرهى ئازادى 99 نئا \\
\hline
\end{tabular}




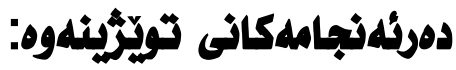

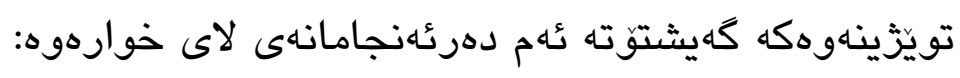

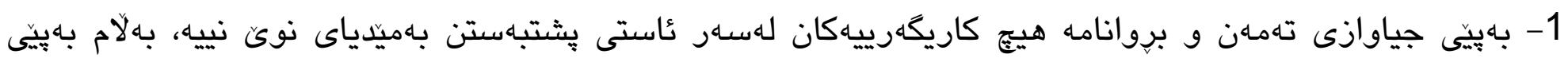

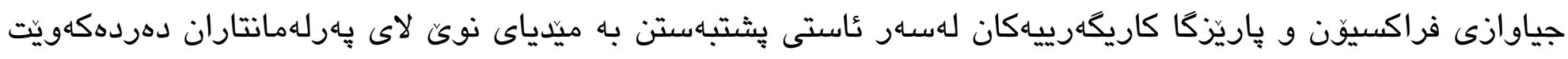
باشيّوهيهكى بهاريزّ.

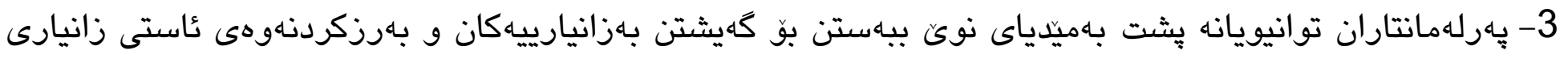
و دروستكردنى بهيوهندى بههيزّ لهنيوان خوّيان و هاوولآتياندا.

טاسيارده:

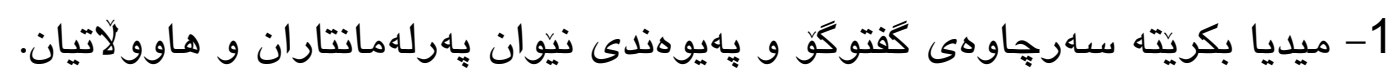

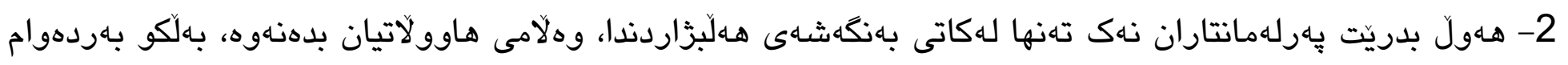
بن لهسهر وهلامدانهوه و يشتكيرى كردنيان.

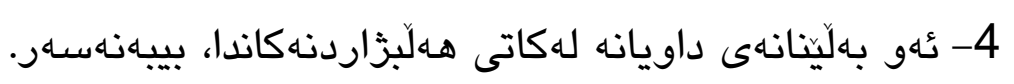

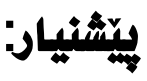

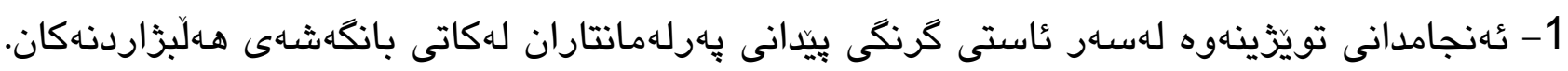

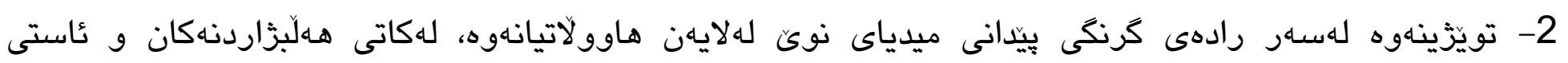

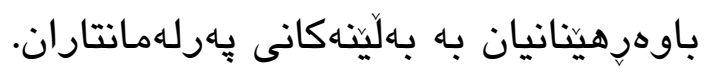




\title{
The Level of Kurdistan Region MPs' Dependency on New Media
}

\author{
Barham Khalid Ahmed \\ Media Department, College of Humanities, University of Sulaimani, Sulaimani, Kurdistan Region, \\ Iraq. \\ E-mail: barham.ahmed@univsul.edu.iq
}

\section{Fuad Ali Ahmed}

Media Department, College of Humanities, University of Sulaimani, Sulaimani, Kurdistan Region, Iraq.

E-mail: fuad.ahmed@univsul.edu.iq

\begin{abstract}
:
In the past decade media industry particularly traditional media has seen a significant decline as new media growth and become an important source for the whole society in developed countries. Albeit politicians have affected by new media impacts as replaced traditional media in many aspects. The new media has a great role for politicians to use it to get information, their publicity, and publishing their activities. This research paper explores the role of new media on Kurdistan region member of parliaments seeking how they rely on new media platforms to find out the MPs dependency on New Media in their works as a public figure.
\end{abstract}

Key Words: Dependence, Kurdistan MPs, New Media, Social Media. 


$$
\begin{aligned}
& \text { : } \\
& \text { حسن عماد مكاوي و عاطف عدلي العبد، نظريات الإعلام، القاهرة، } 2007 . \\
& \text { صالح خليل أبو أصبع، الاتصال الجماهيري، عمان، دار البركة للنشر و التوزيع، } 2010 . \\
& \text { صالح خليل أبو أصبع، الإتصال و الإعلام في المجتمعات المعاصرة، ط5، عمان، دار مجدلاوي للنشر و التوزيع، } 2006 . \\
& \text { محمود حسن إسماعيل، مباديء علم الاتصال ونظريات التأثير، القاهرة، الدار العالمية للنشر و التوزيع، } 2003 .
\end{aligned}
$$

Oxford Dictionaries |English, (2018), new media | Definition of new media in English by Oxford Dictionaries, [Online] Available at: https://en.oxforddictionaries.com/definition/new_media [Accessed 5 Nov. 2018].

Oxfordlearnersdictionaries.com, (2019), decision-making noun - Definition, pictures, pronunciation and usage notes | Oxford Advanced Learner's Dictionary at OxfordLearnersDictionaries.com.

https://www.oxfordlearnersdictionaries.com/definition/english/decision making?q=decisionmaking [Accessed 3 Aug. 2019].

Encyclopedia Britannica, (2019), Rupert Murdoch | Biography \& Facts

https://www.britannica.com/biography/Rupert-Murdoch [Accessed 18 Oct. 2019].

Techopedia.com, (2018), What is New Media? - Definition from Techopedia. [online] Available at:

https://www.techopedia.com/definition/416/new-media [Accessed 5 Nov. 2018].

Elmirabayrasli.com. Available at: http://elmirabayrasli.com/books/the-new-media-theory reader [Accessed 10 Nov. 2018].

Dewdney, A. and Ride, P, (2006), the new media handbook. London: Routledge.

Gibloa, E. (2005) 'Global television news and foreign policy: debating the CNN effect' International Studies Perspectives, 6 .

KALATHIL, S. \& BOAS, T. C, (2003),. Open networks, closed regimes: the impact of the Internet on authoritarian rule, Washington, D.C., Carnegie Endowment for International Peace.

Kember, S. and Zylinska, J, (2015), Life after new media, Cambridge (Mass.): MIT

Koch-Baumgarten, Sigrid \& Voltmer, Katrin, (2010), Public Policy and Mass Media, the Interplay of Mass Communication and Political Decision Making. 
Louw, P. (2010),the media and political process. Los Angeles, Calif: Sage.

Lu, J., Jain, L. and Zhang, G, (2012), Handbook on decision making, Heidelberg: Springer.

Matthew Loveless, (2008), Media Dependency: Mass Media as Sources of Information in the Democratizing Countries of Central and Eastern Europe ,Center for Research and Social Progress (CeRSP), Ph.D. Political Science. MCQUAIL, D, (2010), McQuail's Mass communication theory. London, Sage Publications.

Melvin L. Defleur \& Sandra Ball Rokeach, (1982), Theories of Mass Communication, 4th ed, New York:Longman. McLuhan, M, (1960), Effects of the improvements of communication media, Journal of Economic History.

Robinson, P,(2002), The CNN Effect: The Myth of News, Foreign Policy an Intervention, London: Routledge. Stanyer, J, (2008), Modern political communication. Cambridge: Polity.

Francis Fukuyama, State Building: Governance and World in the Twenty-First.

Street, J., (2010), Mass Media, Politics and Democracy: Second Edition. Palgrave.

Trewatha, R.L., \& Newport, M.G, (1982), Management. 3rd ed., Business Publications.

Triantaphyllou, E., Shu, B., Nieto Sanchez, S., \& Ray, T, (1998), Multi-criteria decision making: An operations research approach. Encyclopedia of Electrical and Electronics Engineering, 15.

Harris, R, (2019), Introduction to Decision Making, Part 1. [online] Virtualsalt.com. Available at: https://www.virtualsalt.com/crebook5.htm [Accessed 9 Sep. 2019].

Lester, P. M. (2011). Visual communication: images with messages. Boston. MA, Wadsworth.

SearchMicroservices, (2018), What is new media? - Definition from WhatIs.com. [online] Available at: https://searchmicroservices.techtarget.com/definition/new-media [Accessed 5 Nov. 2018].

Jones, P, (2019), Decision Making and Decision Taking: they are different. [online] Excitant. Available at: https://www.excitant.co.uk/decision-making-and-decision-taking-they-are-different/ [Accessed 6 Aug. 2019].

M.Igbaria, M.Tan, 1997, the consequences of information technology acceptance on subsequent individual performance. Information \& Management Volume 32, Issue 3, March 1997, Pages 113-121

Micha Kaufman, 2012, The Internet Revolution is the New Industrial Revolution. Accessed 24 October 2018, <http:www.forbes.com> 
Merrill Morris, Christine Ogan; The Internet as Mass Medium, Journal of Computer Mediated Communication, Volume 1, Issue 4, 1 March 1996, JCMC141, https://doi.org/10.1111/j.1083-6101.1996.tb00174.

Taha Najim, http://drtahanegm.blogspot.com/2011/11/blog-post_6684.html: in 7/8/2016.

Theme, E. (2018). Download PDF by Robert Hassan, Julian Thomas: The New Media Theory Reader - Elmira Bayrasli E-books. [online]

Veronica Hefner, (2014), the Influence of Television and Film Viewing on Midlife Women's Body Image, Disordered Eating, and Food Choice, Article.

تعريف و شرح و معنى نموذج اتخاذ القرار بالعربي في معاجم اللغة العربية معجم المعاني الجامع، المعجم الوسيط ،اللغة العربية المعاصرة ،الرائد ،لسان العرب ،القاموس المحيط - معجم عربي عربي صفحة 10 . [online] Almaany.com. Available at: https://www.almaany.com/ar/dict/ar-ar. [Accessed 9 Sep. 2019]. . https://www.alukah.net/culture/0/63677/ [Accessed 9 Sep. 2019].www.alukah.net. (2019), ظافر آل جميلة (29-3-2017)، "مفهوم اتخاذ القرار"، جامعة بابلـ كلية الاقتصاد والإدارة، اطلع عليه بتاريخ 9-9-2019. : عادل ثابت،النظرية السياسية الحديثة : دراسة للنماذج والنظرياتا ليقدم لفهم وتفسرعالم السياسة،( القاهرة،مكتبةخوارزم، 2002م) 


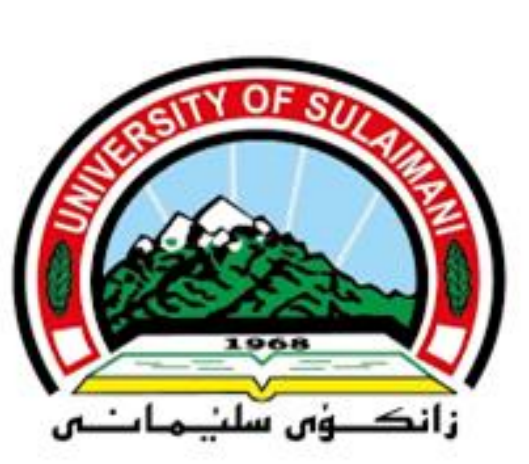

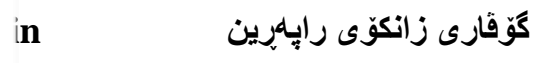

E-ISSN: $2522-7130$ P-ISSN: 2410 - 1036

زانكزى سليمانى

كوليجى زانسته مروقايهتييهكان

بهشى راكهياندن

فَورم

بهيَّ ئهدامى هـرلهمانى كوردستان

بابهت/ فوّمى زانيارى تويّزينهوهى زانستى (دكثقرا)

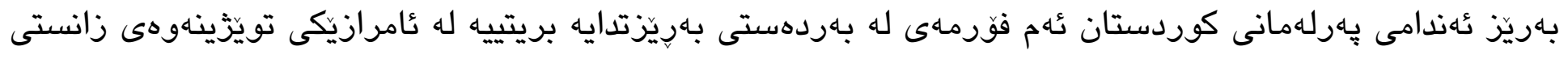

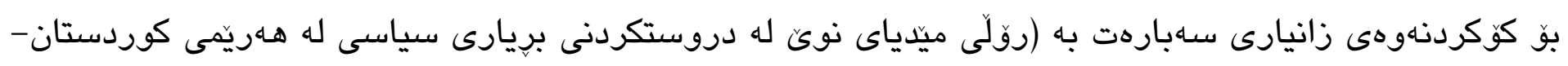

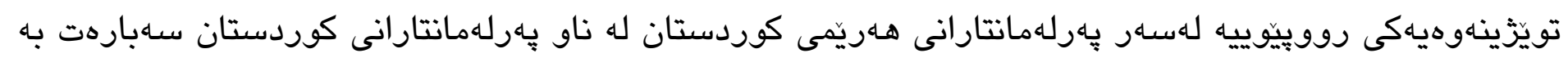

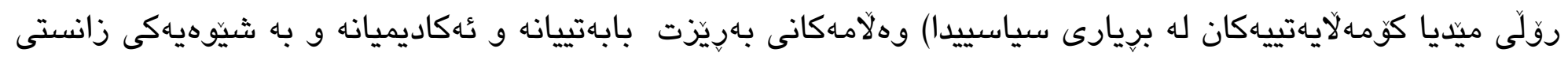

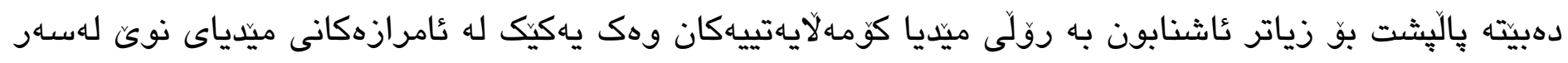

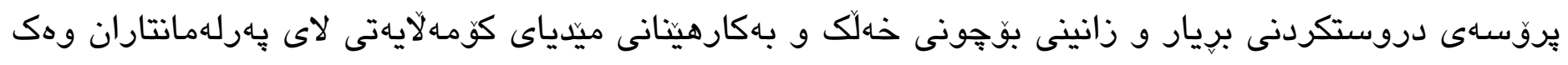

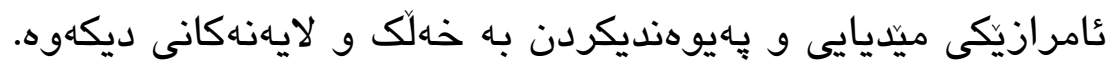

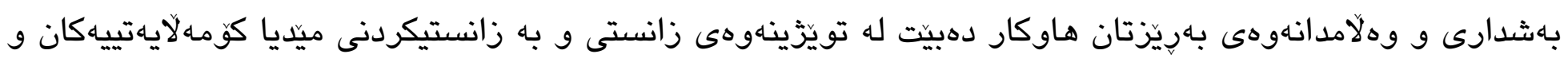

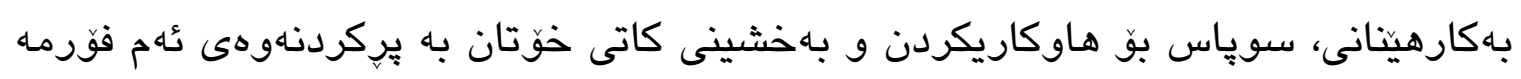

سوياست دهكهين كه وهلامى سهرجهم برسيارهكان بدهيتهوه و تويّزينهوهكهان دهولَمهند بيت به وهلامهكانت، سوياس بو هاوكاريكردنتان.

سهريهرشتيار: بِروَفيسوّى ياريدهدهر، د.فواد على احمد تويَّرَهر: بهرهـام خالد احمد 


\begin{tabular}{|c|c|c|c|c|c|c|c|c|c|}
\hline & & & \multicolumn{3}{|c|}{ 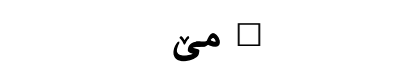 } & \multicolumn{3}{|c|}{ 口 نيّر } & توخم \\
\hline & & \multicolumn{2}{|c|}{ 口 · • و بـردوثوور } & \multicolumn{2}{|c|}{$0 \varepsilon-\varepsilon 0 \square$} & \multicolumn{2}{|c|}{$\varepsilon \varepsilon-r \cdot \square$} & $r \varepsilon-r_{0} \square$ & تهمهن \\
\hline 口 كتوّرا & 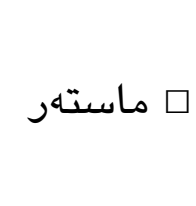 & به بالوَريوّس & 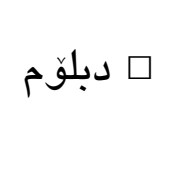 & \multicolumn{2}{|c|}{$\begin{array}{c}\square \\
\text { عامادهيى }\end{array}$} & \multicolumn{2}{|c|}{ 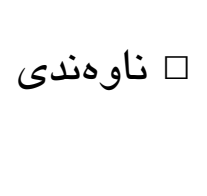 } & سـاهرهتايى & 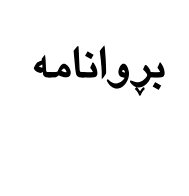 \\
\hline \multirow[t]{3}{*}{ كه كوينائهان } & 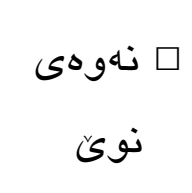 & يـكکرتوو & 口 كوّمـلَ & \multicolumn{2}{|c|}{ 口 كَّران } & \multicolumn{2}{|c|}{ 口 يهكيتى } & 口 پِارتى & \multirow{2}{*}{ فراكسيون } \\
\hline & & & \multicolumn{2}{|c|}{ 口 سـهـربه خوّ } & \multicolumn{2}{|c|}{ 口 نَازادى } & \multicolumn{2}{|c|}{ 口 سـهاردهدم } & \\
\hline & & 口هـلَّبحه & \multicolumn{2}{|l|}{ 口 دهوّك } & \multicolumn{2}{|c|}{ 口 سليّمانى } & \multicolumn{2}{|r|}{ 口 مهـوليّر } & ياريزكا \\
\hline
\end{tabular}


فوّرمى يِيوانهيى تاييهت به رولّى ميّدياى نوى له دروستكردنى برِيارى سياسى له ههريمى كوردستاندا بشت بهستى هبرلهمانتاران به ميدياى نويّ

\begin{tabular}{|c|c|c|c|c|c|c|}
\hline هـهركيز & كهم & هـندي كات & زَود & هـميشه & بركه & زنجيره \\
\hline & & & & & كورديّاى نوكن وا دهكات ئاكَاداربم له هـوال و روداوهكانى & 1 \\
\hline & & & & & 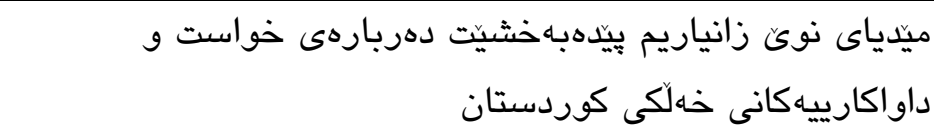 & 2 \\
\hline & & & & & مياسياى نوكيّ وادهات زانيارييهكانم زياد بكات دهربارهى برسه & 3 \\
\hline & & & & & 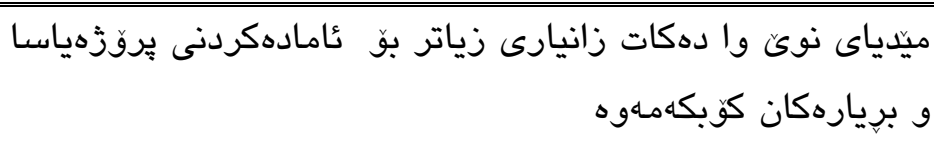 & 4 \\
\hline & & & & & 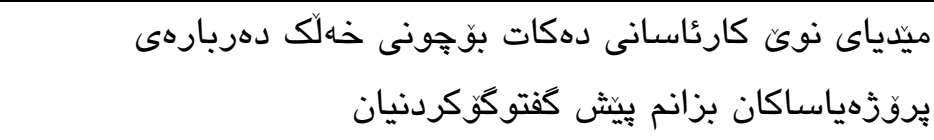 & 5 \\
\hline & & & & & 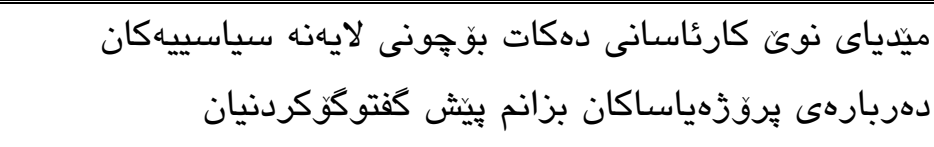 & 6 \\
\hline & & & & & 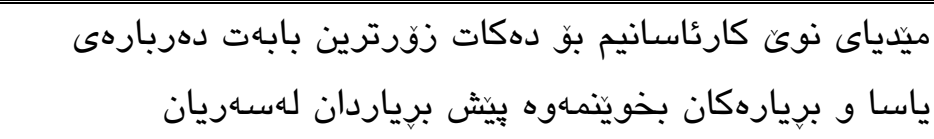 & 7 \\
\hline & & & & & 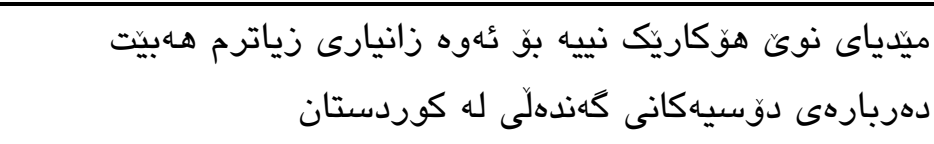 & 8 \\
\hline & & & & & 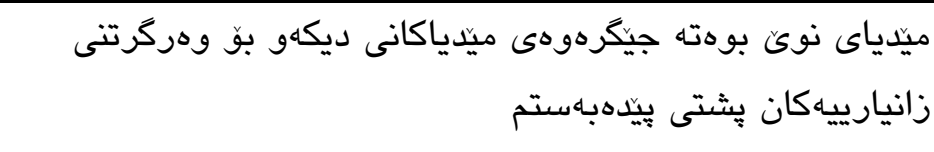 & 9 \\
\hline
\end{tabular}

